\title{
Hubungan Antara Kelekatan kepada Orang Tua dan Dukungan Iman Orang Tua dengan Religiositas Remaja
}

\author{
Enny Dewi, ${ }^{1) *}$ Aileen P. Mamahit, ${ }^{2)}$ Rahmiati Tanudjaja ${ }^{3)}$ \\ ${ }^{1)}$ Lembaga Konseling Keluarga Kreatif \\ 2) 3) Sekolah Tinggi Teologi SAAT, Malang \\ *) Korespondensi: ennydewi12@gmail.com
}

\begin{abstract}
Abstrak: Peran orang tua dalam religiositas remaja sangat penting. Remaja menghadapi banyak tantangan dalam masa pubertas dengan berbagai perkembangan yang cukup kompleks meliputi aspek kognitif, afektif, moral, sosial, dan iman. Peran orang tua dibutuhkan untuk menolong mereka melewati masa ini sehingga mampu mencapai individuasi, termasuk untuk menentukan identitas imannya. Penelitian ini bertujuan untuk melihat apakah terdapat hubungan antara kelekatan dan dukungan iman orang tua dengan religiositas 247 remaja berusia 13-18 tahun yang beribadah di kebaktian remaja di lima jemaat Gereja Kristen Abdiel Gloria di Surabaya. Penelitian kuantitatif ini menggunakan Spearman Rank Correlation untuk analisis data dari tiga kuesioner, yaitu Inventory of Parent and Peer Attachment (IPPA), Perceived Faith Support from Parents and Friends (PFS-P dan PFS-F), dan Intrinsic/Extrinsic Revised Scale. Hasil penelitian menunjukkan korelasi yang signifikan dan positif antara variabel-variabel yang diuji. Semakin tinggi kelekatan kepada orang tua, maka semakin tinggi religiositas remaja; dan semakin tinggi dukungan iman orang tua, maka semakin tinggi religiositas remaja. Sebaliknya, semakin rendah kelekatan kepada orang tua, maka semakin rendah religiositas remaja; dan semakin rendah dukungan iman orang tua, maka semakin rendah religitositas remaja.

Kata-kata kunci: Kelekatan, Dukungan Iman, Religiositas, Remaja
\end{abstract}

Abstract: The role of parents in adolescent religiosity is exceptionally important. Adolescent overcome many challenges in puberty with a variety of developments that are quite complex, including aspects such as cognitive, affective, moral, social, and faith. The role of parents is needed to assist them overcoming this period in order to reach individuation and determine identity of their faith. This study aims to analyze the correlation between attachment and parental faith support to the religiosity of 247 adolescent, aged 13-18 years, who attend youth services in five congregations of Gereja Kristen Abdiel Gloria in Surabaya. This quantitative study was conducted through Spearman Rank Correlation for data analysis from three questionnaires, namely Inventory of Parent and Peer Attachment (IPPA), Perceived Faith Support from Parents and Friends (PFS-P and PFS-F), and Intrinsicl Extrinsic Revised Scale. The research results show that there is a positive and significant relationship between the variables. Higher attachment to parent relates positively to higher religiosity of adolescent. Higher parental faith support relates positively to higher adolescent religiosity and vice versa.

Keywords: Attachment, Faith Support, Religiosity, Adolescent 


\section{PENDAHULUAN}

Bilangan Research Center (BRC) melakukan survei pada semester kedua tahun 2017 yang merupakan survei dengan skala terbesar yang pernah dilakukan lembaga Kristen di Indonesia. Hasil survei tersebut menyatakan bahwa dari 4.095 remaja Kristen yang tersebar di 42 kota di Indonesia, hanya 63,8\% yang mengikuti ibadah empat kali atau lebih dalam satu bulan dan $17,9 \%$ yang rutin membaca Alkitab lima kali atau lebih dalam seminggu. ${ }^{1}$ Hasil survei ini juga menemukan bahwa hanya sebagian kecil remaja yang menjadi orang Kristen dan hidup sesuai dengan nilainilai kekristenan. Sebagian besar pergi ke gereja hanya sebagai rutinitas, tetapi tidak melakukan aktivitas Kristen lainnya, seperti membaca Alkitab, berdoa, dan pelayanan. Sejumlah $8 \%$ responden bahkan menyatakan jarang sekali atau tidak pernah lagi ke gereja, meskipun sebelumnya mereka pergi ke gereja secara rutin.

Hasil penelitian BRC tersebut tidak menggambarkan seluruh remaja Kristen di Indonesia, tetapi dapat mewakili keadaan keagamaan remaja di Indonesia. Fenomena yang terjadi ini perlu mendapat perhatian sebab agama adalah bagian penting dalam kehidupan manusia yang memberi dampak terhadap identitas diri, perilaku, hubungan sosial, dan kesejahteraan remaja. ${ }^{2}$

Konsep tentang pentingnya agama yang dapat diukur disebut dengan istilah religiositas. ${ }^{3}$ Dalam penelitian ini, religiositas yang dimaksud adalah kepercayaan kepada Tuhan, relasi dengan Tuhan, pengabdian kepada Tuhan, dan kesalehan dalam kehidupan sehari-hari,

${ }^{1}$ Bambang Budijanto, ed. Dinamika Spiritualitas Generasi Muda Kristen Indonesia (Jakarta: Bilangan Research Center, 2018), 31.

${ }^{2}$ Melinda Lundquist Denton, "Relationship Quality between Parents and Adolescents: Understanding the Role of Religion" (disertasi, University of North Carolina, 2006), 8, https://dx.doi.org/10.17615/j8j7-0385.

${ }^{3}$ Ralph W. Hood, Peter C. Hill, dan Bernard Spilka, The Psychology of Religion, ed. ke-4 (New York: Guilford, 2009), 126, Adobe PDF ebook. yang merupakan praktik dari apa yang dipercayainya, misalnya pergi ke gereja.

Religiositas remaja tidak dapat dipisahkan dari peran orang tua yang mendidik mereka sejak bayi. Hal ini disebabkan anak-anak memang tidak dapat melihat Allah yang tidak kelihatan, tetapi mereka dapat melihat orang tua yang menyatakan kehadiran Allah. ${ }^{4}$ Orang tua mempunyai tanggung jawab utama bagi perkembangan sosial, moral dan spiritual anak-anak mereka, karena orang tua adalah orang pertama yang meletakkan nilai dasar moral dan agama pada anak-anak, serta mengajarkan kepada mereka untuk mengambil keputusan. ${ }^{5}$

Hal yang penting tetapi sering tidak diperhatikan oleh orang tua pada masa kini dalam mengasuh anaknya adalah membangun kelekatan. Keadaan ini diperparah dengan perkembangan teknologi dan maraknya media sosial, yang membuat remaja dan orang tua lebih lekat kepada gadget-nya daripada dengan anggota keluarga lain. Beberapa penelitian menunjukkan adanya hubungan antara kelekatan dan religiositas remaja, misalnya kelekatan dengan ibu memprediksi remaja untuk mengadopsi kepercayaan agama orang tua mereka. ${ }^{6}$ Hubungan yang hangat dan peduli dari ibu dan ayah juga menjadi salah satu faktor penting bagi remaja untuk terus berkomitmen hadir di gereja. ${ }^{7}$ Di sisi lain, kelekatan

${ }^{4}$ Sungwon Kim, "Parenting Styles and Children's Spiritual Development," dalam Nurturing Children's Spirituality: Christian Perspectives and Best Practices, ed. Holly Catterton Allen (Oregon: Cascade, 2008), 242.

${ }^{5}$ Eleanor E. Maccoby, "Parenting and its Effects on Children: On Reading and Misreading Behavior Genetics," Annual Review of Psychology 51, no. 1 (2000): 3, diakses 19 Oktober 2017, https://www.doi.org/10.1146/annurev. psych.51.1.1.

${ }^{6} \mathrm{Pehr}$ Granqvist, "Attachment and Religiosity in Adolescence: Cross-Sectional and Longitudinal Evaluations," Personality and Social Psychology Bulletin 28, no. 2 (2002): 266, diakses 30 Oktober 2017, http://dx.doi. org/10.1177/0146167202282011.

${ }^{7}$ Roger L. Dudley dan Randall L. Wisbey, "The Relationship of Parenting Styles to Commitment to the Church among Young Adults," Religious Education 95, no. 1 (2000): 49, diakses 23 Agustus 2017, ATLASerials. 
tidak aman secara umum berkaitan dengan ketidakstabilan dalam religiositas. ${ }^{8}$

Selain kelekatan, orang tua juga berperan dalam religiositas remaja dengan dukungan iman yang diberikan. Penelitian yang dilakukan Kelly Dean Schwartz menemukan bahwa orang tua dan teman secara signifikan dan positif memprediksi religiositas remaja. ${ }^{9}$ Orang tua dapat memberi dampak terhadap perkembangan religiositas anak dengan memberikan dukungan iman, baik melalui komunikasi verbal maupun contoh perilaku. Jika kualitas komunikasi dalam keluarga tinggi, maka kecil kemungkinan remaja akan meninggalkan imannya. ${ }^{10}$ Remaja juga cenderung meniru pemodelan spiritual orang tua, seperti perilaku orang tua yang secara rutin dan konsisten menghadiri kebaktian. ${ }^{11}$ Orang tua yang religius-menganggap iman adalah hal yang penting-cenderung menghasilkan remaja yang menghadiri ibadah secara rutin pula. $^{12}$

Berdasarkan pemaparan di atas, penelitian ini mengajukan hipotesis sebagai berikut: (1) ada hubungan antara religiositas remaja dengan kelekatan remaja kepada orang tua. Semakin tinggi kelekatan kepada orang tua, maka semakin tinggi religiositas remaja; dan (2) da hubungan antara religiositas remaja dengan dukungan iman orang tua. Semakin

${ }^{8}$ Ibid.

${ }^{9}$ Kelly Dean Schwartz, "Transformations in Parent and Friend Faith Support Predicting Adolescents' Religious Faith," The International Journal for the Psychology of Religion 16, no. 4 (2006): 311, diakses 28 September 2017, http://dx.doi.org/10.1207/s15327582ijpr1604_5.

${ }^{10}$ Toon W. Taris dan Gün R. Semin, "Passing on the Faith: How Mother-Child Communication Influences Transmission of Moral Values," Journal of Moral Education 26, no. 2 (1997): 219, diakses 18 Desember 2017, http://dx.doi.org/10.1080/0305724970260208.

\footnotetext{
${ }^{11}$ Wan-Ning Bao et al., "Perceived Parental Acceptance as a Moderator of Religious Transmission among Adolescent Boys and Girls," Journal of Marriage and the Family 61, no. 2 (1999): 370, diakses 30 Oktober 2017, http://dx.doi. org/10.2307/353754.

${ }^{12}$ Christian Smith dan Melinda Lundquist Denton, Soul Searching: The Religious and Spiritual Lives of American Teenagers (New York: Oxford University Press, 2005), 91, Adobe PDF ebook.
}

tinggi dukungan iman orang tua, maka semakin tinggi religiositas remaja.

\section{TINJAUAN PUSTAKA}

\section{Religiositas}

Religiositas mencakup 4 dimensi inti, yaitu kepercayaan, praktik (ritual/umum dan devotional), pengalaman, dan pengetahuan. ${ }^{13}$ Dimensi kepercayaan menunjukkan bahwa orang yang religius akan berpegang pada kepercayaan yang diyakininya. ${ }^{14}$ Keyakinan ini disebut juga dengan iman yang menyatakan sejauh mana agama merupakan bagian penting dalam identitas dirinya. ${ }^{15}$ Iman mencakup konsep tentang Tuhan dan bagaimana dampak ilahi bekerja terhadap nilai inti, kepercayaan, dan makna dalam kehidupan pribadi individu, dan juga dalam hubungannya dengan orang lain. ${ }^{16}$ Dimensi praktik mencakup praktik keagamaan yang diharapkan untuk dipahami dan dilakukan oleh para pemeluk agama. ${ }^{17}$ Rodney Stark dan Charles Y. Glock menyebut ritual sebagai dimensi praktik yang bersifat publik dan devotional sebagai dimensi praktik yang bersifat personal.

Dimensi pengalaman berkaitan dengan harapan bahwa orang yang religius dapat mencapai pengetahuan tentang Tuhan secara langsung sehingga dapat mengalami perasaan atau emosi religius. ${ }^{18}$ Pengalaman akan

${ }^{13}$ Rodney Stark dan Charles Y. Glock, American Piety: The Nature of Religious Commitment (Berkeley: University of California Press, 1968), 16, Adobe PDF ebook.

${ }^{14}$ Charles Young Glock, "On the Study of Religious Commitment," Religious Education 57, no. 4 (1962): 99, diakses 7 November 2017, http://dx.doi. org/10.1080/003440862057S407.

${ }^{15}$ Lisa D. Pearce dan Melinda Lundquist Denton, $A$ Faith of Their Own (New York: Oxford University Press, 2011), 13.

${ }^{16}$ Pamela Ebstyne King dan Robert R. Roeser, "Religion and Spirituality in Adolescent Development," dalam Handbook of Adolescent Psychology, ed. Richard M. Lerner dan Laurence Steinberg, ed. ke-3 (New Jersey: John Wiley \& Sons, 2009), 445.

${ }^{17}$ Glock, "On the Study," 99.

${ }^{18}$ Ibid. 
kehadiran Allah dan keintiman yang dirasakan akan mendorong orang yang beragama untuk melakukan dan menyatakan imannya dalam praktik agama. Dimensi pengetahuan berkaitan dengan harapan bahwa orang beragama akan mempunyai informasi dan pengetahuan tentang ajaran dasar iman dan kitab sucinya. ${ }^{19}$

Salah satu teori tentang religiositas yang banyak mendapat perhatian adalah teori Gordon W. Allport tentang religiositas intrinsik dan ekstrinsik. Allport mengambil dari aksiologi konsep tentang nilai ekstrinsik dan nilai intrinsik untuk membuat perbedaan terhadap keduanya. Dia menjelaskan bahwa orang yang pergi ke gereja dengan tujuan untuk mendapatkan manfaat bagi diri mereka sendiri disebut memiliki religiositas ekstrinsik. Sementara orang yang pergi ke gereja dengan tujuan akhir agama itu sendiri, karena menganggap bahwa iman adalah nilai tertinggi, disebut memiliki religiositas intrinsik. ${ }^{20}$

Orang dengan religiositas ekstrinsik beranggapan bahwa agama dapat digunakan untuk mendapatkan manfaat bagi diri mereka sendiri. Mereka juga beranggapan bahwa prasangka merupakan hal yang menguntungkan karena memberikan kepada mereka rasa aman, nyaman, status, dan dukungan sosial sehingga tidak masalah bagi mereka untuk bersikap menghakimi dan tidak toleransi. ${ }^{21}$ Sejalan dengan pemikiran Allport, Richard L. Gorsuch memberikan definisi komitmen religiositas intrinsik sebagai motivasi untuk mengalami dan menjalani kepercayaan religius demi keimanan itu sendiri; tanpa adanya penguatan eksternal. ${ }^{22}$ Penekanan definisi ini

\section{${ }^{19}$ Ibid.}

${ }^{20}$ Gordon W. Allport, "The Religious Context of Prejudice," Journal for the Scientific Study of Religion 5, no. 3 (1966): 454, diakses 4 November 2017, http://dx.doi. org/10.2307/1384172.

${ }^{21}$ Gordon W. Allport dan J. Michael Ross, "Personal Religious Orientation and Prejudice.," Journal of Personality and Social Psychology 5, no. 4 (1967): 432, diakses 3 November 2017, http://dx.doi.org/10.1037/h0021212.

${ }^{22}$ Richard L. Gorsuch, "Toward Motivational Theories of Intrinsic Religious Commitment," Journal for the terletak pada motivasi individu dalam beragama, yaitu tujuan dan keinginan individu untuk mengalami dan menjalani kepercayaan agama adalah karena iman/agama itu sendiri. Motivasi ini bukan karena adanya penyebab eksternal yang lain, misalnya, mendapat berkat, mendapat teman, mempunyai status sosial, mendapatkan ketenangan, penghiburan, maupun rasa aman.

Berdasarkan pemaparan teori Allport di atas, hal ini berarti bahwa orang yang pergi ke gereja sekalipun dapat mempunyai sikap negatif, yaitu lebih bersifat menghakimi, membedakan ras atau etnik dibandingkan mereka yang tidak pergi ke gereja. ${ }^{23}$

Di sisi lain, orang yang memiliki religiositas intrinsik beranggapan bahwa agama bukan alat, cara atau obat untuk mendapatkan keuntungan. Kebutuhan orang ini hanya menundukkan diri pada komitmen agama dan menginternalisasikannya dalam kehidupan dengan nilai-nilai kasih sayang. Dengan demikian, tidak ada tempat bagi penghinaan, penolakan, atau sikap menghakimi. ${ }^{24}$

Religiositas umumnya berhubungan dengan hal positif, misalnya, kesehatan mental yang lebih baik pada remaja ${ }^{25}$ dan mempunyai efek positif pada sikap serta perilaku hidup sehat. ${ }^{26}$ Religiositas juga dinyatakan berhubungan positif dengan nilai dan perilaku prososial; dan berhubungan negatif dengan ide dan usaha bunuh diri, penggunaan obat bius, kekerasan, keterlibatan seksual yang

Scientific Study of Religion 33, no. 4 (1994): 317, diakses 6 November 2017, http://dx.doi.org/10.2307/1386491.

${ }^{23}$ Allport, "The Religious Context," 447.

${ }^{24}$ Allport dan Ross, "Personal Religious Orientation and Prejudice," 441.

${ }^{25}$ Y. Joel Wong, Lynn Rew, dan Kristina D. Slaikeu, "A Systematic Review of Recent Research on Adolescent Religiosity/Spirituality and Mental Health," Issues in Mental Health Nursing 27, no. 2 (2006): 161, diakses 23 Oktober 2017, http://dx.doi.org/10.1080/01612840500436941.

${ }^{26}$ Lynn Rew dan Y. Joel Wong, "A Systematic Review of Associations among Religiosity/Spirituality and Adolescent Health Attitudes and Behaviors," Journal of Adolescent Health 38, no. 4 (2006): 433, diakses 23 Oktober 2017, http://dx.doi.org/10.1016/j.jadohealth.2005.02.004. 
terlalu dini. ${ }^{27}$ Religiositas telah banyak dikaitkan dengan berbagai macam isu, salah satunya berasal dari Kelly James Bonewell. Dia menyebutkan bahwa terdapat hubungan positif antara religiositas intrinsik dengan rendahnya kompulsivitas seksual dan hubungan positif antara religiositas ekstrinsik dengan tingginya kompulsivitas seksual. ${ }^{28}$ Religiositas intrinsik juga dinyatakan berkorelasi negatif dengan kecemasan akan kematian dan berkorelasi positif dengan kepercayaan akan kehidupan setelah kematian. Sebaliknya, religiositas ekstrinsik berkorelasi positif dengan kecemasan akan kematian dan berkorelasi negatif dengan kepercayaan akan kehidupan setelah kematian. ${ }^{29}$

\section{Religiositas Remaja}

Religiositas remaja mempunyai ciri tersendiri karena berkaitan dengan perkembangan pada masa remaja, baik secara fisik, psikologis, kognitif, moral dan sosial. Melalui teori psikososialnya, Erik Erikson menyebutkan bahwa remaja merupakan tahap ketika individu sedang berada pada krisis kehidupan untuk menentukan identitas dirinya. Jika individu tidak mampu meraih identitas tersebut, maka ia akan mengalami kebingungan. ${ }^{30}$ Perkembangan yang terjadi ini juga memberi dampak terhadap perkembangan iman remaja, yaitu mereka dihadapkan pada tahap

${ }^{27}$ Michael J. Donahue dan Peter L. Benson, "Religion and the Well-Being of Adolescents," Journal of Social Issues 51, no. 2 (1995): 145, diakses 23 Oktober 2017, http://dx.doi.org/10.1111/j.1540-4560.1995.tb01328.x.

\footnotetext{
${ }^{28}$ Kelly James Bonewell, "Intrinsic and Extrinsic Religiosity and Sexual Compulsivity with Christian Males: Understanding Concepts and Correlations Based on Race, Age and Socio-Economic Status and Marital Status," (disertasi, Capella University, 2010), 89, http:// www.kellybonewell.com/wp-content/uploads/2010/11/ Intrinsic-and-Extrinsic-Religiosity-and-Sexual-Compulsivity-with-Christian-Males-Understanding-Correlations-and-Concepts-Kelly-James-Bonewell.pdf.

${ }^{29}$ Adam B. Cohen et al., "Intrinsic and Extrinsic Religiosity, Belief in the Afterlife, Death Anxiety, and Life Satisfaction in Young Catholics and Protestants," Journal of Research in Personality 39, no. 3 (2005): 314, diakses 22 November 2017, https://doi.org/10.1016/j.jrp.2004.02.005.
}

${ }^{30}$ Erik H. Erikson, Childhood and Society (Albury: Imago, 1951), 235, Adobe PDF ebook. identifikasi dan pembentukan iman secara pribadi. ${ }^{31}$ James Fowler menyebut tahap ini sebagai tahap perkembangan Synthetic-Conventional. Dalam tahap ini remaja diharapkan dapat mengambil keputusan sendiri untuk menentukan iman dan kepercayaannya menurut apa yang dipandangnya benar, yang akan dipegangnya sebagai identitas religiusnya.

Kemampuan remaja untuk dapat mengambil keputusan sendiri dimungkinkan karena adanya perkembangan kognitif. Menurut Jean Piaget, perkembangan kognitif remaja bergerak dari tahap operasional konkret ke tahap operasional formal. Hal ini bermakna bahwa pemikiran remaja tidak hanya terbatas pada pengalaman-pengalaman yang aktual atau konkret, tetapi mulai dapat memikirkan hal-hal yang lebih abstrak, yang mengandung idealisme dan kemungkinan-kemungkinan. ${ }^{32}$ Dalam kaitannya dengan relasi dengan orang lain, tahap operasional formal memunculkan dimensi baru, yaitu individu dapat melihat perspektif orang lain tentang diri. ${ }^{33}$ Membangun perspektif diri dari perspektif orang lain, juga termasuk melihat diri dari perspektif Tuhan, yang pada akhirnya akan membawa perubahan pada tahapan perkembangan moral. Tokoh perkembangan moral, Lawrence Kohlberg menyatakan tahap perkembangan moral remaja terletak pada level kedua tahap ketiga, yang disebut mutual interpersonal expectations, relationship and interpersonal conformity. ${ }^{34}$ Motif yang kuat pada tahap ini adalah untuk menyenangkan orang-orang yang sangat penting, dan tidak mengecewakan pendapat maupun harapan mereka. ${ }^{35}$

Pada masa remaja, pengalaman individu tentang dunia tidak hanya terbatas pada keluarga,

\footnotetext{
${ }^{31}$ James W. Fowler, Stages of Faith: The Psychology of Human Development and The Quest for Meaning (New York: Harper Collins, 1981), 290.

${ }^{32}$ John W. Santrock, Perkembangan Masa Hidup Jilid 1, terj. Benedictine Widyasinta, ed. ke-13 (Jakarta: Erlangga, 2011), 423.

${ }^{33}$ Fowler, Stages of Faith, 72.

${ }^{34}$ Ibid., 74.

${ }^{35} \mathrm{Ibid}$.
} 
tetapi makin luas ke lingkungan sekolah, teman sebaya, masyarakat dan lingkungan agama, yang masing-masing mempunyai nilai dan ideologi yang berbeda. ${ }^{36}$ Dengan perkembangan moral dan kognitifnya yang sudah mampu berpikir abstrak, remaja mempunyai tugas dalam perkembangan iman untuk menyimpulkan nilai-nilai dan informasi yang berbeda tersebut menjadi satu keyakinan yang menjadi dasar atas pandangan dan identitas dirinya.

Dampak religiositas remaja terhadap aspek kognitif dapat dilihat dari pendidikan remaja, misalnya motivasi terhadap pendidikan ${ }^{37}$ dan keberhasilan di bidang akademik. ${ }^{38}$ Dalam kesejahteraan emosi, remaja yang lebih religius akan merasa bahagia dan sedikit yang merasa tidak puas dengan penampilan fisiknya. ${ }^{39}$ Remaja religius juga cenderung tidak merasa sendirian, sedih, depresi, maupun disalahpahami atau tidak dipedulikan orang. ${ }^{40}$ Mereka mampu merasakan hidup yang lebih bermakna serta mampu merencanakan masa depannya. Hal ini berarti remaja religius memiliki sikap dan persepsi yang lebih positif tentang hidup dan masa depan, yang berkaitan dengan kesejahteraan yang lebih besar. ${ }^{41}$

Dampak religiositas terhadap perilaku remaja cukup bervariasi, baik terhadap perilaku yang positif maupun negatif. Religiositas menunda debut seksual remaja perempuan, ${ }^{42}$

\section{${ }^{36}$ Ibid., 172.}

${ }^{37}$ Mark D. Regnerus, "Shaping Schooling Success: Religious Socialization and Educational Outcomes in Metropolitan Public Schools," Journal for the Scientific Study of Religion 39, no. 3 (2000): 369, diakses 29 November 2017, http://dx.doi.org/10.1111/0021-8294.00030.

${ }^{38}$ Mark D. Regnerus dan Glen H. Elder, "Staying on Track in School: Religious Influences in High- and LowRisk Settings," Journal for the Scientific Study of Religion 42, no. 4 (2003): 645, diakses 29 November 2017, http:// dx.doi.org/10.1046/j.1468-5906.2003.00208.x.

${ }^{39}$ Smith dan Denton, Soul Searching, 225.

${ }^{40}$ Ibid.

${ }^{41}$ Ibid., 226.

${ }^{42}$ Sharon Scales Rostosky et al., "The Impact of Religiosity on Adolescent Sexual Behavior: A Review of the Evidence," Journal of Adolescent Research 19, remaja yang lebih religius juga lebih sedikit menggunakan internet untuk membuka, melihat dan menonton situs, film, dan video porno. Mereka juga lebih sedikit menggunakan waktu untuk bermain video game yang bersifat kekerasan dan mampu menahan diri untuk tidak melakukan hubungan seks sebelum menikah. ${ }^{43}$ Religiositas remaja juga terkait dengan perubahan perilaku berisiko, yaitu penggunaan narkoba dan keterlibatan untuk menjadi warga negara yang baik. ${ }^{44}$ Keterkaitan yang lain adalah remaja religius lebih sedikit yang merokok, minum alkohol, mengisap mariyuana, membolos/diusir dari sekolah, dan mempunyai nilai buruk di sekolah. ${ }^{45}$ Sementara kaitannya dengan religiositas intrinsik, remaja yang memilikinya mempunyai pencapaian identitas yang lebih stabil karena mereka menginternalisasikan komitmennya ${ }^{46}$ memiliki self-control yang tinggi, ${ }^{47}$ serta tingkat depresi yang lebih rendah. ${ }^{48}$

\section{Kelekatan}

Tokoh pertama yang memperkenalkan teori kelekatan adalah John Bowlby, yang menyatakan bahwa kelekatan adalah perilaku naluriah

no. 6 (2004): 677, diakses 23 Oktober 2017, http://doi. org/10.1177/0743558403260019.

${ }^{43}$ Smith dan Denton, Soul Searching, 223.

${ }^{44}$ Michael Kerestes, James Youniss, dan Edward Metz, "Longitudinal Patterns of Religious Perspective and Civic Integration," Applied Developmental Science 8, no. 1 (2004): 39, diakses, 23 Oktober 2017, http://dx.doi. org/10.1207/S1532480XADS0801_5.

${ }^{45}$ Smith dan Denton, Soul Searching, 221.

${ }^{46}$ Aubyn S. Fulton, "Identity Status, Religious Orientation, and Prejudice," Journal of Youth and Adolescence 26, no. 1 (1997): 8, diakses 29 November 2017, http://dx.doi. org/10.1023/A:1024519227129.

${ }^{47}$ Michael E. McCullough dan Brian L. B. Willoughby, "Religion, Self-Regulation, and Self-Control: Associations, Explanations, and Implications," Psychological Bulletin 135, no. 1 (2009): 73, diakses 29 Oktober 2017, http:// dx.doi.org/10.1037/a0014213.

${ }^{48}$ Sarah W. Helms et al., "Intrinsic Religiosity Buffers the Longitudinal Effects of Peer Victimization on Adolescent Depressive Symptoms," Journal of Clinical Child and Adolescent Psychology 44, no. 3 (2015): 476, diakses 29 November 2017, http://dx.doi.org/10.1080/15374416.2013. 865195. 
yang berakar secara biologis dan dengan demikian menjadi ciri khas makhluk hidup, ${ }^{49}$ yang terkait dengan pemeliharaan diri..$^{50}$ Kelekatan akan membawa individu untuk mempunyai perilaku kelekatan. Sebagai contoh, bayi akan menangis ketika ibu meninggalkan dirinya. Ini adalah perilaku kelekatan yang ditunjukkan bayi, yang secara naluriah berusaha dekat dan menjaga agar ibu tetap berada di dekatnya dan tidak meninggalkannya. ${ }^{51}$

Perilaku kelekatan merupakan segala bentuk perilaku yang mengakibatkan individu dapat mencapai atau mempertahankan kedekatan dengan beberapa individu teridentifikasi lainnya yang dianggap lebih mampu mengatasi dunia. ${ }^{52}$ Menurut Bowlby, perilaku kelekatan ini dapat diamati sepanjang siklus kehidupan manusia, khususnya ketika terjadi keadaan darurat. $^{53}$

Bagi seorang anak, ketiadaan figur kelekatan yang dibutuhkan adalah sebuah ancaman atau keadaan darurat. Oleh karena itu, ketika figur kelekatan yang dicari tidak ada, ia akan menunjukkan perilaku kelekatan dengan mencari figur lain yang dia kenal dan berada di dekatnya. ${ }^{54}$ Mencari figur kelekatan juga menunjukkan adanya kebutuhan akan rasa aman. Ketika bayi bertambah besar, ia juga perlu merasa aman di tempat yang asing, dengan figur kelekatan lain selain ibu, misalnya guru di sekolah. ${ }^{55}$

Bowlby menyebutkan rekan kerjanya Mary Ainsworth, sebagai tokoh pertama yang

${ }^{49}$ Mary S. Ainsworth, "Attachments Beyond Infancy," American Psychologist 44, no. 4 (1989): 709, diakses 30 Oktober 2017, http://dx.doi.org/10.1037/0003-066X.44.4.709.

${ }^{50}$ John Bowlby, Attachment, Attachment and Loss 1. (New York: Basic, 1982), 52, Adobe PDF ebook.

${ }^{51}$ Ibid., 122.

${ }^{52}$ John Bowlby, A Secure Base: Parent-Child Attachment and Healthy Human Development (New York: Basic, 1990), 26, Adobe PDF ebook.

\footnotetext{
${ }^{53}$ Bowlby, A Secure Base, 26.

${ }^{54}$ Ibid., 27.

${ }^{55}$ Bowlby, Attachment, 174.
}

menguraikan tentang kelekatan aman. ${ }^{56}$ Ainsworth menggunakan istilah ikatan perasaan untuk menggambarkan kelekatan, yaitu ikatan yang terjadi relatif dalam jangka waktu yang lebih lama. Hal ini berarti individu yang merasakan kelekatan akan menganggap orang yang pernah menjadi figur kelekatan sebagai individu yang penting, unik, dan tidak dapat ditukar atau digantikan dengan yang lain, meskipun di kemudian hari ada figur lain yang melekat kepadanya. ${ }^{57}$ Dalam penelitiannya di Uganda, Ainsworth menemukan bahwa bayi akan secara aktif mencari kedekatan dengan ibu ketika mereka gugup atau terluka, juga ketika ibu pergi walaupun hanya sebentar, dan ketika mereka lapar. ${ }^{58}$ Hal ini menunjukkan bahwa pada umumnya bayi memandang ibu sebagai dasar keamanan mereka untuk menjelajah dunia sekaligus tempat berlindung yang aman.

Ainsworth menyimpulkan adanya tiga macam kelekatan, yaitu bayi dengan kelekatan aman (secure attachment), kelekatan tidak aman (insecure attachment), dan tidak ada kelekatan (nonattached). ${ }^{59}$ Bayi dengan kelekatan aman akan sedikit menangis, kecuali ibu tidak ada atau kelihatan akan meninggalkan dirinya. ${ }^{60}$ Bayi dengan kelekatan tidak aman banyak menangis meskipun ada ibu; mereka menginginkan kontak fisik secara terus-menerus dengan ibu, namun juga bersikap ambivalen terhadap kehadiran ibu. ${ }^{61}$ Bayi yang tidak ada kelekatan akan bersikap sama, baik kepada ibu atau orang dewasa lain, yaitu tidak kecewa

\footnotetext{
${ }^{56}$ Ibid., 277.

${ }^{57}$ Ainsworth, “Attachments Beyond Infancy,” 711.

${ }^{58}$ Bowlby, Attachment, 171.
}

${ }^{59}$ Mary S. Ainsworth dan John Bowlby, "An Ethological Approach to Personality Development," American Psychologist 46, no. 4 (1991): 338, diakses 9 November 2017, http://dx.doi.org/10.1037/0003-066X.46.4.333.

${ }^{60}$ Ibid.

${ }^{61}$ Marinus H. van IJzendoorn dan Abraham SagiSchwartz, "Cross-Cultural Patterns of Attachment," dalam Handbook of Attachment: Theory, Research, and Clinical Applications, ed. Jude Cassidy dan Phillip R. Shaver, ed. ke-2 (New York: Guilford, 2008), 880, Adobe PDF ebook. 
ketika ditinggalkan dan tidak memberi respons ketika ibu kembali.

Ainsworth dan Bowlby mengutip disertasi Blatz yang memberikan sorotan terhadap teori keamanan dalam teori kelekatannya, dan menyebutkan tentang immature dependent security dan mature dependent security. ${ }^{62}$ Menurut Blatz, bayi menunjukkan immature dependent security karena bayi dapat merasa aman hanya jika dapat bergantung sepenuhnya pada figur orang tua untuk memelihara mereka. Orang tua dianggap bertanggung jawab atas konsekuensi dari perilaku mereka; dan mampu memberikan rasa aman kepadanya. Ketika bayi bertambah besar, ia harus mengembangkan mature dependent security, yaitu sikap yang saling berkontribusi serta hubungan saling memberi dan menerima. Hal ini bermakna, melalui pengetahuan dan keterampilannya, masing-masing individu dapat memberi dasar keamanan satu sama lain. ${ }^{63}$

\section{Kelekatan Aman}

Unsur pertama dalam kelekatan aman adalah kepercayaan. Bayi akan menunjukkan kelekatan ketika merasakan bahwa orang tua menerima dan mengasihinya. Hal ini terjadi ketika bayi merasa bahwa orang tua menunjukkan kepekaan dalam menangkap tanda dan komunikasi yang ditunjukkannya, yaitu ketika ia merasa lapar, sakit, maupun takut. Jika orang tua mampu menunjukkan tanda demikian, maka kelekatan ini dapat terjadi meskipun bayi berada pada situasi atau keadaan yang asing ${ }^{64}$ karena bayi telah percaya dan merasa aman.

Kepercayaan anak terhadap orang tua adalah titik pangkal kepercayaan anak terhadap hal yang lain. ${ }^{65}$ Teori psikososial Erikson

\footnotetext{
334.

${ }^{62}$ Ainsworth dan Bowlby, "An Ethological Approach,"

${ }^{63}$ Ibid., 335.

${ }^{64}$ Mary D. Slater Ainsworth et al., Patterns of Attachment: A Psychological Study of the Strange Situation (New York: Psychology Press, 1978), 181.

${ }^{65}$ Joseph J. Godfrey, Trust of People, Words, and God (Notre Dame: University of Notre Dame Press, 2012), 106.
}

mengatakan bahwa setiap individu dihadapkan pada krisis yang merupakan suatu tugas perkembangan unik yang harus diselesaikannya. Dalam tahun-tahun pertama kehidupannya, bayi dinyatakan menghadapi tugas untuk membangun rasa percaya atau tidak percaya ${ }^{66}$ Jika orang tua menunjukkan kelekatan yang aman, maka bayi akan bertumbuh dengan memiliki rasa percaya, bukan hanya pada figur kelekatan ibu, tetapi juga pada orang lain dan dunia yang ada di sekitarnya. Adanya figur yang dapat dipercayai dan memberi dukungan, rasa aman serta perlindungan akan membuat anak memiliki keyakinan bahwa dalam keadaan sulit, mereka mempunyai figur yang selalu ada untuk mereka. ${ }^{67}$

Unsur kedua dalam kelekatan aman adalah komunikasi, baik secara verbal maupun nonverbal. Pada awalnya, ekspresi emosi dan tingkah laku merupakan satu-satunya sarana komunikasi antara orang tua dan bayi. Misalnya, senyuman ibu dapat menyatakan persetujuan dan hal ini memberitahu bayi bahwa ia berada pada jalan yang benar. Sebaliknya, jika ibu mengerutkan keningnya, berarti ia tidak menyetujui. ${ }^{68}$ Kepekaan orang tua menanggapi tanda yang diberikan mengomunikasikan kepada anak bahwa tanda itu mempunyai arti dan bernilai bagi orang tua. Dengan demikian, anak menjadi lebih percaya diri dalam mengekspresikan kebutuhan mereka secara bebas, karena mereka tahu bahwa orang tua akan memberi respons dengan tepat. ${ }^{69}$ Anak yang sudah lebih besar melihat ketidakhadiran figur kelekatan dalam waktu lama, emosi yang tidak stabil, atau adanya tanda penolakan dan pengabaian, sebagai bentuk komunikasi nonverbal, yang akan

\footnotetext{
${ }^{66}$ Santrock, Perkembangan Masa Hidup, 423.

${ }^{67}$ John Bowlby, Separation: Anxiety, and Anger, Attachment and Loss 2 (New York: Basic, 1973), 162, Adobe PDF ebook.

${ }^{68}$ Bowlby, Separation, 100.

${ }^{69}$ Ayelet Etzion-Carasso dan David Oppenheim, "Open Mother-Pre-Schooler Communication: Relations with Early Secure Attachment," Attachment \& Human Development 2, no. 3 (2000): 348.
} 
mengakibatkan perasaan kecemasan, kemarahan, dan kesedihan. ${ }^{70}$

Individu yang mempunyai kelekatan aman dan merasa aman dengan dirinya akan terampil dalam mengomunikasikan perasaan serta opini mereka. ${ }^{71}$ Komunikasi dapat mengalir bebas dengan ekspresi perasaan yang ditunjukkan dan menyentuh berbagai topik, termasuk yang bersifat personal. ${ }^{72} \mathrm{Hal}$ ini berarti, anak dengan kelekatan aman akan mempunyai komunikasi yang terbuka, sedangkan anak dengan kelekatan tidak aman cenderung mengembangkan komunikasi yang tertutup. ${ }^{73}$

\section{Kelekatan Remaja kepada Orang Tua}

Remaja mempunyai tugas yang cukup penting, yaitu mereka ditantang untuk menemukan identitas diri dan memikirkan ulang hubungannya dengan orang tuanya. ${ }^{74} \mathrm{Di}$ dalam usahanya mencari identitas diri, remaja berusaha untuk berevolusi. Jika pada awalnya mereka bertindak sebagai penerima kelekatan, sekarang menjadi mandiri dan tidak bergantung lagi pada orang tua sebagai figur kelekatan. Selanjutnya, mereka bahkan dapat menjadi figur kelekatan bagi teman sebaya, pasangan romantis, dan keturunannya. ${ }^{75}$ Remaja yang berhasil dalam negosiasi dengan perpisahan

${ }^{70}$ Roger Kobak dan Stephanie Madsen, "Disruptions in Attachment Bonds: Implications for Theory, Research, and Clinical Intervention," dalam Handbook of Attachment: Theory, Research, and Clinical Applications, ed. Jude Cassidy dan Phillip R. Shaver, ed. ke-2 (New York: The Guilford, 2008), 24, Adobe PDF ebook.

${ }^{71}$ Tim Clinton dan Gary Sibcy, Attachment: Why You Love, Feel and Act the Way You Do (Brentwood: Integrity, 2012), 130.

${ }^{72}$ Ibid., 129.

${ }^{73}$ Ibid.

${ }^{74}$ Jessica Samuolis, Kiera Layburn, dan Kathleen M. Schiaffino, "Identity Development and Attachment to Parents in College Students," Journal of Youth and Adolescence 30, no. 3 (2001): 373, diakses 15 Agustus 2017, http:// dx.doi.org/10.1023/A:1010448313516.

${ }^{75}$ Joseph P. Allen, "The Attachment System in Adolescence," dalam Handbook of Attachment: Theory, Research, and Clinical Applications, ed. Jude Cassidy dan Phillip R. Shaver, ed. ke-2 (New York: Guilford, 2008), 419, Adobe PDF ebook. dan individuasi dengan figur kelekatan dianggap telah menetapkan tonggak sejarah baru dalam pembentukan identitas dirinya. ${ }^{76}$

Salah satu faktor yang menyebabkan remaja dapat berhasil dalam usaha negosiasi tersebut adalah peran orang tua, yang mengizinkan dan memberi kebebasan kepada remaja bahkan sampai usia dewasa muda untuk mandiri dan mengeksplorasi dirinya. Peran ini juga mencakup penerimaan orang tua dengan tangan terbuka ketika remaja mengalami tekanan yang berat. ${ }^{77}$ Peran orang tua ini berhubungan dengan kepercayaan dan komunikasi yang dilakukan untuk menolong perkembangan kognitif, afektif dan perilaku remaja. Melalui kepercayaan dan penerimaan yang didapat, remaja dapat menyatakan apa yang ada dalam pemikirannya dengan bebas tanpa rasa takut. Remaja juga dapat mengembangkan sisi afektif dalam dirinya sebab kepercayaan dan komunikasi akan membuat remaja menjadi aman dengan dirinya sehingga gejolak emosi yang biasa terjadi di masa remaja dapat diatasi. Remaja dengan kelekatan aman juga mampu mengembangkan kapasitas empati karena dapat mengidentifikasi emosi orang lain. ${ }^{78}$

Kelekatan aman juga memberikan dampak positif dalam perkembangan sosial remaja, yaitu mereka dapat menjalin relasi dengan kepercayaan dan juga tanggap dengan isyarat sosial yang muncul. ${ }^{79}$ Ketika remaja merasa dikasihi, diterima, dan dihargai; dampak terhadap perilaku juga muncul. Kelekatan aman membangun penghargaan terhadap diri sendiri, yang akan menghasilkan kehidupan sosial remaja yang positif, dan cenderung dapat mengatasi masalah perilaku seperti

\footnotetext{
${ }^{76}$ Samuolis, Layburn, dan Schiaffino, "Identity Development and Attachment," 374.

${ }^{77}$ Ibid., 421.

${ }^{78}$ Nancy S. Weinfield et al., "Individual Differences in Infant-Caregiver Attachment: Conceptual and Empirical Aspects of Security," dalam Handbook of Attachment: Theory, Research, and Clinical Applications, ed. Jude Cassidy dan Phillip R. Shaver, ed. ke-2 (New York: Guilford, 2008), 87, 89, Adobe PDF ebook.
}

${ }^{79}$ Ibid., 89. 
perilaku agresif dan kekerasan. ${ }^{80}$ Mereka juga mempunyai rasa percaya diri akan dukungan keluarga sehingga dapat mengembangkan diri keluar dari keluarga, termasuk membentuk hubungan yang baru dengan teman sebaya dan orang dewasa. ${ }^{81}$ Remaja dengan kelekatan kepada orang tua yang rendah atau negatif berhubungan dengan tingkat perilaku kejahatan yang lebih tinggi, ${ }^{82}$ dan lebih cenderung mempunyai perilaku yang berisiko daripada remaja yang secara keseluruhan mempunyai kelekatan positif dengan orang tuanya. ${ }^{83}$

Hubungan antara religiositas dan kelekatan dapat dijelaskan melalui beberapa penelitian yang telah dilakukan. Anak yang mempunyai kelekatan aman akan membangun konsep kepercayaan dan harapan tentang figur kelekatan sebagai seseorang yang dapat diandalkan, hadir dan responsif, dan pemikiran ini akan dibawa dalam hubungan yang lain, termasuk hubungan dengan Tuhan. ${ }^{84}$ Kelekatan tidak aman dengan orang tua berhubungan dengan religiositas yang didasarkan pada emosi, dan kelekatan tidak aman dengan ibu berhubungan dengan menurunnya religiositas. ${ }^{85}$ Heuikwang Sin mengemukakan pola kelekatan dengan orang tua yang stabil dan

${ }^{80}$ Ho Ming Chong, "The Impact of Parental Attachment on Adolescent Externalizing Problem Behaviour in Hong Kong," Department of Applied Social Studies (2007): 37.

${ }^{81}$ W. Andrew Collins dan Brett Laursen, "Parent-Adolescent Relationships and Influences," dalam Handbook of Adolescent Psychology, ed. Richard M. Lerner dan Laurence Steinberg, ed. ke-2 (Hoboker: John Wiley \& Sons, 2004), 334, Adobe PDF ebook.

${ }^{82}$ MacHteld Hoeve et al., "A Meta-Analysis of Attachment to Parents and Delinquency," Journal of Abnormal Child Psychology 40, no. 5 (2012): 778, diakses 11 Desember 2017, https://dx.doi.org/10.1007/s10802-011-9608-1.

${ }^{83}$ Loranie Leas dan David Mellor, "Prediction of Delinquency: The Role of Depression, Risk-Taking, and Parental Attachment," Behaviour Change 17, no. 3 (2000): 161, diakses 11 Desember 2017, http://dx.doi.org/10.1375/ bech.17.3.155.

${ }^{84}$ Lee A. Kirkpatrick, Attachment, Evolution, and the Psychology of Religion (New York: Guilford, 2005), 111, Adobe PDF ebook.

${ }^{85}$ Granqvist, "Attachment and Religiosity," 266. aman dapat membangun kelekatan dengan Tuhan yang aman pula. Sebaliknya, individu dengan kelekatan tidak aman ditemukan sulit percaya pada orang lain dan membangun sikap yang negatif dalam hubungannya dengan orang lain, termasuk dengan Tuhan. ${ }^{86}$ Religiositas orang dewasa ditemukan berasal dari sejarah kelekatan aman masa kecil, yaitu ketika mereka mengadopsi kepercayaan kepada Tuhan dari orang tua mereka sebagai figur kelekatan. ${ }^{87}$

\section{Dukungan Iman Orang Tua}

Tugas orang tua adalah mendidik dan mengasuh anak-anak, baik secara moral, kognitif, afektif maupun perilaku mereka. Sebagai individu yang percaya kepada Tuhan, orang tua juga mempunyai tanggung jawab untuk mengajarkan tentang agama dan memperkenalkan Tuhan kepada anak-anak mereka. Cara yang dipakai adalah dengan mengajak anak untuk berpikir tentang Tuhan secara mendalam, dengan melibatkan aspek emosi, pribadi, dan sosial, ${ }^{88}$ melalui perkataan, sikap atau perilaku. Peran orang tua tersebut merupakan dukungan bagi remaja untuk menentukan sikap dan nilai hidup, yang kemudian akan memimpin mereka bertindak berdasarkan nilai tersebut. Dalam kehidupan beragama, peran orang tua ini merupakan dukungan iman bagi remaja.

Salah satu teori yang digunakan untuk menjelaskan tentang dukungan iman adalah teori pembelajaran sosial dengan tokohnya Albert Bandura. ${ }^{89}$ Teori yang disebut dengan teori kognitif sosial ini mengandung satu aspek

\footnotetext{
${ }^{86}$ Heuikwang Shin, "Asian-American College Students' Parental Attachment and Their Relationship with God," Christian Education Journal 6, no. 2 (2009): 366, diakses 6 September 2017, https://doi. org/10.1177/073989130900600212.

${ }^{87}$ Kirkpatrick, Attachment, Evolution, 129.

${ }^{88}$ Chris J. Boyatzis, "Religious and Spiritual Development in Childhood," dalam Handbook of the Psychology of Religion and Spirituality, ed. Raymond F. Paloutzian dan Crystal L. Park (New York: The Guilford, 2005), 127, Adobe PDF ebook.
}

${ }^{89}$ Mark Kelland, "Social Learning Theory and Personality Development," OpenStax-CNX Modules (1963): 1. 
penting yang menyatakan bahwa manusia mempunyai fleksibilitas untuk belajar berbagai sikap, kemampuan, dan perilaku dalam situasi yang berbeda-beda dengan cara mengobservasi orang lain..$^{90}$ Melalui fleksibilitas untuk belajar ini, manusia menjadi agen perubahan yang berpartisipasi penuh dalam lingkungan yang ada. ${ }^{91}$

Manusia dapat berubah karena mempunyai kemampuan untuk belajar, dan manusia juga telah mengembangkan kemampuan kognitif yang lebih maju untuk pembelajaran observasional, yang memungkinkan mereka membentuk dan menyusun kehidupan mereka melalui kekuatan pemodelan. ${ }^{92}$ Sejarah tradisi agama juga menekankan pentingnya untuk dekat dengan orang baik, orang bijaksana, dan orang kudus, dengan alasan bahwa individu cenderung akan menjadi seperti individu lain yang berhubungan dekat dengannya. ${ }^{93}$ Proses ini disebut dengan pemodelan spiritual, yaitu belajar keterampilan dan perilaku spiritual dengan cara mengobservasi orang lain. ${ }^{94}$

Proses sosialisasi dari pembelajaran sosial orang tua ke anak akan terjadi lebih mendalam melalui internalisasi, yang dikonseptualisasikan dengan dua cara, yaitu transmisi budaya dan transformasi budaya. ${ }^{95}$ Dalam model transmisi budaya, nilai dari orang tua disampaikan kepada anak dengan cara tidak

${ }^{90}$ Jess Feist dan J. Feist, Gregory, Teori Kepribadian Buku 2, terj. Smita Prathita Sjahputri (Jakarta: Salemba Humanika, 2014), 203.

${ }^{91}$ Kelland, Social Learning Theory, 3.

${ }^{92}$ Albert Bandura, "Commentary: 'On the Psychosocial Impact and Mechanisms of Spiritual Modeling," International Journal for the Psychology of Religion 13, no. 3 (2003): 167, diakses 14 November 2017, https://doi.org/10.1207/ S15327582IJPR1303_02.

${ }^{93}$ Doug Oman dan Carl E. Thoresen, "Spiritual Modeling: A Key to Spiritual and Religious Growth?," The International Journal for the Psychology of Religion 13, no. 3 (2003): 150, diakses Oktober 31, 2017, http://dx.doi. org/10.1207/S15327582IJPR1303_01.

${ }^{94}$ Ibid.

${ }^{95}$ Jeanette A. Lawrence dan Jaan Valsiner, “Conceptual Roots of Internalization: From Transmission to Transformation," Human Development 36 (1993): 152, diakses 14 November 2017, http://dx.doi.org/10.1159/000277333. disengaja. Anak dipandang sebagai penerima pasif, yang menerima nilai yang ditransmisikan oleh orang tua, yang dipandang sebagai agen aktif dalam proses internalisasi. ${ }^{96}$ Sementara dalam model transformasi budaya, nilai eksternal ditransformasikan menjadi nilai internal melalui proses kognitif dalam diri individu. ${ }^{97}$ Proses dua arah atau timbal balik terjadi dalam proses ini; ${ }^{98}$ orang tua dan anak sama-sama menjadi agen aktif dalam proses internalisasi. ${ }^{99}$ Douglas L. Flor dan Nancy Flanagan Knapp menyebut proses transformasi ini sebagai transactional process (proses transaksional). ${ }^{100}$

Persepsi remaja terhadap dukungan iman orang tua berhubungan dengan perkembangan kognitif, afektif, dan sosial atau perilaku. Perkembangan kognitif menyebabkan remaja mulai dapat berpikir abstrak dan logis. Salah satu ciri perkembangan ini adalah remaja mulai mengembangkan gambaran mengenai keadaan ideal, misalnya konsep orang tua ideal dan membandingkan orang tua mereka dengan standar ideal yang ada dalam pemikiran abstrak mereka. ${ }^{101}$ Selain itu, remaja juga mempertimbangkan gagasan, ide, dan nilai ideal, termasuk sifat atau tipe nilai agama yang diinternalisasikan oleh orang tuanya. Nilai atau kepercayaan religius yang diinternalisasikan akan makin kuat diterima jika nilai yang ditransmisikan bersifat jelas dan konkret. ${ }^{102} \mathrm{Hal}$ ini dapat terjadi jika

${ }^{96}$ Douglas L. Flor dan Nancy Flanagan Knapp, “Trans-
mission and Transaction: Predicting Adolescents' Inter-
nalization of Parental Religious Values," Journal of Family
Psychology 15, no. 4 (2001): 627.

${ }^{97}$ Lawrence dan Valsiner, "Conceptual Roots of Internalization," 152.

${ }^{98}$ Ibid., 164.

${ }^{99}$ Richard M. Ryan dan Cynthia L. Powelson, "Autonomy and Relatedness as Fundamental to Motivation and Education," Journal of Experimental Education 60, no. 1 (1991): 61. 627.

${ }^{100}$ Flor dan Knapp, "Transmission and Transaction,"

${ }^{101}$ Santrock, Perkembangan Masa Hidup, 29.

${ }^{102}$ Dean R. Hoge, Gregory H. Petrillo, dan Ella I. Smith, "Transmission of Religious and Social Values from 
orang tua sendiri mempunyai keyakinan yang jelas terhadap nilai agama yang akan diinternalisasikan tersebut.

Perkembangan emosi pada masa remaja cukup kompleks karena masa remaja adalah masa transisi dari kanak-kanak menuju dewasa, yang penuh gejolak dan tekanan, baik tekanan dari dalam maupun dari luar, yang memberi dampak pada emosi remaja yang mudah berubah dan sangat tergantung dengan suasana hati. Hal ini akan tampak lebih jelas dalam relasi atau hubungan dengan orang lain, khususnya dengan orang tua, keluarga, dan teman sebaya. Kualitas hubungan orang tua yang dekat akan memberi dampak terhadap internalisasi nilai agama oleh orang tua kepada remaja. ${ }^{103}$ Hubungan yang dekat akan membuat remaja peduli terhadap apa yang menjadi nilai atau kepercayaan orang tua dan berusaha untuk memenuhinya sehingga proses internalisasi dapat berjalan dengan baik dan berhasil. Orang tua yang menjalin hubungan yang baik dengan anakanaknya menyediakan suasana yang kondusif untuk mengajarkan tentang moral, termasuk agama, dan memudahkan mereka menanamkan nilai-nilai yang dipegang mereka kepada anak-anak. ${ }^{104}$

Dalam perkembangan sosial, remaja mempunyai kesempatan yang lebih besar dalam lingkup sosial yang lebih luas untuk berbagi pendapat, kesan, dan pengalaman dengan orang lain. ${ }^{105} \mathrm{Hal}$ ini menyebabkan remaja menjadi rentan mengubah kepercayaan dan praktik agamanya. Kemungkinan ini dapat diatasi orang tua dengan menciptakan lingkungan

Parents to Teenage Children," Journal of Marriage and the Family 44, no. 3 (1982): 570, diakses 14 November 2017, http://dx.doi.org/10.2307/351580.

${ }^{103}$ Mark D. Regnerus, "Religion and Positive Adolescent Outcomes: A Review of Research and Theory," Review of Religious Research 44, no. 4 (2003): 404, diakses 23 Oktober 2017, http://dx.doi.org/10.2307/3512217.

${ }^{104}$ Taris dan Semin, "Passing on the Faith," 212.

${ }^{105}$ Elizabeth Weiss Ozorak, "Social and Cognitive Influences on the Development of Religious Beliefs and Commitments in Adolescence," Journal for the Scientific Study of Religion 28, no. 4 (1989): 449, diakses 30 November 2017, http://dx.doi.org/10.2307/1386576. sosial yang dapat dipakai sebagai sarana untuk menginternalisasikan nilai agama kepada anak-anaknya. Sebagai contoh, orang tua dapat menghadiri kebaktian di gereja yang sama, melakukan doa bersama, dan melaksanakan ibadah keluarga. Bagi remaja, menjadi anggota gereja yang sama dengan orang tua juga dapat memberikan identitas sosial, yang merupakan bagian dari identitas dirinya sebagai pribadi. ${ }^{106}$

\section{Model Dukungan Iman}

Dukungan iman orang tua kepada remaja diberikan dengan model yang hampir sama seperti yang dilakukan orang tua ketika memberikan ajarannya pada bidang yang lain, yaitu melalui induksi verbal dan indoktrinasi kepercayaan, taktik disiplin, dan model perilaku. ${ }^{107}$ Dalam kaitannya dengan perkembangan iman, maka model perilaku merupakan faktor dominan yang memengaruhinya.

Model perilaku akan lebih meresap dalam diri anak jika digabungkan dengan proses internalisasi, yaitu dengan model transmisi dan transaksional. Model transmisi lebih bersifat satu arah, yaitu orang tua yang dianggap lebih tahu akan memberikan contoh lengkap tentang pengetahuan dan perilaku agama kepada anak yang belum atau kurang tahu. Anak sebagai penerima diharapkan dapat menerima dengan pasif tanpa rekonstruksi ulang. ${ }^{108}$ Model transmisi dinilai lebih berhasil untuk memprediksi perilaku religius, namun kurang berhasil untuk memprediksi sikap terhadap iman agama. ${ }^{109}$

\footnotetext{
${ }^{106}$ Robert H. Bradley, "Environment and Parenting," dalam Handbook of Parenting Volume 2 Biology and Ecology of Parenting, ed. Marc H. Bornstein (Mahwah: Lawrence Erlbaum Associates, 2002), 307, Adobe PDF ebook. 131.

${ }^{107}$ Boyatzis, "Religious and Spiritual Development,"

${ }^{108}$ Lawrence dan Valsiner, "Conceptual Roots of Internalization," 152.

${ }^{109}$ Leslie J. Francis dan Harry M. Gibson, "Parental Influence and Adolescent Religiosity: A Study of Church Attendance and Attitude Toward Christianity Among Adolescents 11 to 12 and 15 to 16 Years Old," International Journal for the Psychology of Religion 3, no. 4 (1993): 250, diakses 17 Desember 2017, ATLA Serials.
} 
Model perilaku juga dapat dilakukan dengan model transaksional, yaitu cara yang menunjukkan adanya hubungan timbal balik dalam interaksi agama, yang menjadi ciri kebanyakan percakapan orang tua-anak yang sehat. ${ }^{110}$ Selain ada hubungan timbal balik, model transaksional juga merupakan suatu proses aktif yang melibatkan tindakan dan motivasi tertentu; serta mengintegrasikan aspek dunia sosial dengan diri intrinsik seseorang. ${ }^{111}$ Meskipun proses sosialisasi merupakan otoritas orang tua dengan menekankan standar nilai dan perilaku kepada anak yang menerima secara pasif, sosialisasi yang efektif tetap membutuhkan penyesuaian yang muncul dari dalam diri anak itu sendiri. ${ }^{112}$

Schwartz mendefinisikan dukungan iman orang tua sebagai proses sosialisasi iman yang diberikan orang tua melalui model iman dan dialog iman. ${ }^{113}$ Tujuan dari dukungan iman orang tua adalah agar remaja memiliki kompetensi untuk menetapkan sendiri identitas imannya. Dalam penelitiannya, Schwartz menggabungkan model transmisi (faith modeling) dan model transaksional (faith dialogue). ${ }^{114}$ Penggunaan kedua model tersebut menunjukkan keduanya mempunyai keunggulan berbeda, yang dapat digunakan bersama-sama untuk mendapatkan hasil yang lebih baik. Model transmisi tampak lebih jelas karena muncul dalam perilaku, yaitu orang tua memberikan model iman (faith modeling). Contoh yang paling sering digunakan untuk mengukur keberhasilan model transmisi adalah dengan melihat kehadiran di gereja ${ }^{115}$ dan kesamaan kepercayaan atau

\footnotetext{
${ }^{110}$ Schwartz, "Transformations in Parent," 312.

${ }^{111}$ Wendy S. Grolnic, Edward L. Deci, dan Richard M. Ryan, "Internationalization within the Family: The Self-Determination Theory Perspective," dalam Parenting and Children's Internalization of Values: A Handbook of Contemporary Theory, ed. Joan E. Grusec dan Leon Kuczynski (New York: Wiley, 1997), 136.

${ }^{112}$ Ibid., 135.

${ }^{113}$ Schwartz, "Transformations in Parent," 314.

${ }^{114}$ Ibid.

${ }^{115}$ Bao et al., "Perceived Parental Acceptance," 365.
}

perilaku orang tua-anak. ${ }^{116}$ Model transaksional dilakukan melalui dialog iman atau diskusi dua arah tentang iman kepercayaan. ${ }^{117}$ Dialog iman atau diskusi yang dimaksudkan bukan hanya komunikasi biasa antara orang tua dan remaja, tetapi merupakan komunikasi dengan motivasi dan tujuan agar nilai, sikap, dan perilaku yang akan diinternalisasikan kepada remaja dapat terwujud. Di dalam model transaksional terdapat tanggung jawab bersama antara orang tua dan remaja. Kedua belah pihak terlibat dalam proses yang terusmenerus untuk mengevaluasi pengalaman, kepercayaan, dan perilaku. ${ }^{118}$

Bill J. Mowry mengungkapkan tiga hal penting yang terdapat dalam model transaksional, yaitu nilai dan kepercayaan inti, konteks, dan natur komunikasi. ${ }^{119}$ Nilai dan kepercayaan inti dari orang tua tentang agama dapat menolong untuk menentukan konteks apa yang ingin dicapai dalam proses internalisasi orang tua kepada anak. Hal ini dilakukan dengan komunikasi yang mempertimbangkan kepekaan dan berorientasi pada penerima, yaitu remaja. ${ }^{120}$ Orang tua tidak mengasumsikan bahwa mereka tahu segalanya dan menetapkan tujuan untuk remaja, sebaliknya mereka melakukan komunikasi untuk mengetahui kebutuhan atau pendapat remaja. ${ }^{121} \mathrm{Hal}$ ini menunjukkan bahwa orang tua menghargai remaja sebagai pribadi yang mempunyai kehendak bebas dan melalui komunikasi dengan remaja, orang tua mengizinkan adanya perbedaan, tetapi juga melakukan negosiasi

${ }^{116}$ Alan C. Acock and Vern L. Bengtson, "On the Relative Influence of Mothers and Fathers: A Covariance Analysis of Political and Religious Socialization," Journal of Marriage and Family 40, no. 3 (1978): 524, diakses 19 Desember 2017, http://dx.doi.org/10.2307/350932. 629.

${ }^{117}$ Flor dan Knapp, “Transmission and Transaction,"

${ }^{118}$ Bill J. Mowry, "A Contextualized/Transactional Model for Leadership Development," Christian Education Journal 13, no. 1 (1992): 63, diakses 17 Desember 2017, ATLASerials.

\footnotetext{
${ }^{119}$ Ibid., 64.

${ }^{120}$ Ibid., 66.

${ }^{121}$ Ibid., 67.
} 
agar kebutuhan masing-masing pihak dapat dipenuhi. Setelah ada kesepakatan, komunikasi dilanjutkan untuk menetapkan tujuan yang akan dicapai dan juga strategi yang akan digunakan untuk mencapai tujuan tersebut. ${ }^{122}$ Model transaksional juga memerlukan evaluasi dan pertanggungjawaban, yaitu ketika orang tua memperteguh, membenarkan atau mengoreksi remaja di dalam hubungan yang hangat. ${ }^{123}$ Jika hal ini dilakukan, maka proses transformasi akan terjadi; karena nilai, kepercayaan, juga perilaku akan dikritik, dipelajari, dan berubah dalam proses perkembangannya.

Dampak dukungan iman orang tua terkait dengan dinamika kehidupan remaja, misalnya terhadap penghargaan diri, identitas diri, konformitas, religiositas, ${ }^{124}$ dan makin berkurangnya partisipasi remaja dengan masalah perilaku. ${ }^{125}$ Kepercayaan dan praktik religius orang tua yang menjadi model iman merupakan jangkar kognitif bagi anak. Hal ini berarti bahwa ketika menginjak masa remaja, anak dapat memilih afiliasi dan kepercayaan yang sama dengan orang tuanya, walaupun seiring pertumbuhannya, keyakinan anak dapat berevolusi. ${ }^{126}$ Di negara Barat, kegagalan untuk melakukan transmisi nilai agama dari satu generasi ke generasi berikutnya merupakan faktor yang menyebabkan menurunnya identitas dan praktik agama dalam beberapa masyarakat tertentu. ${ }^{127}$ Dengan demikian,

${ }^{122}$ Ibid., 68.

${ }^{123}$ Ibid., 69.

${ }^{124}$ Andrew J. Weigerta dan Darwin L. Thomas, "Parental Support, Control and Adolescent Religiousity: An Extension of Previous Research," Journal for the Scientific Study of Religion 11, no. 4 (1972): 389, diakses September 28, 2017, ATLA Serials.

${ }^{125}$ Shirley L. Jessor and Richard Jessor, "Maternal Ideology and Adolescent Problem Behavior," Developmental Psychology 10, no. 2 (1974): 250, diakses 18 Desember 2017, http://dx.doi.org/10.1037/h0035991.

${ }^{126}$ Ozorak, "Social and Cognitive Influences," 460.

${ }^{127}$ Mark Chaves, "Secularization and Religious Revival: Evidence from U.S. Church Attendance Rates, 19721986," Journal for the Scientific Study of Religion 28, no. 4 (1989): 467, diakses 19 Desember 2017, http://dx.doi. org/10.2307/1386577. model transmisi merupakan faktor penting bagi keyakinan iman anak.

Remaja yang menyaksikan orang tuanya sebagai model iman yang kuat dan konsisten dengan gaya hidup Kristen cenderung menampakkan kepercayaan yang kuat di dalam Tuhan, mengintegrasikan iman dalam kehidupannya dan berpartisipasi dalam kegiatan agama. ${ }^{128}$ Todd F. Martin dkk. menemukan bahwa peran penting orang tua dalam perkembangan kedewasaan iman remaja mempunyai efek jangka panjang. ${ }^{129}$ Efek model transaksional dengan diskusi iman dua arah mempunyai dampak penting pembentukan perilaku agama remaja serta dalam memprediksi pentingnya agama bagi mereka. ${ }^{130}$ Komunikasi orang tua-remaja yang bersifat membangun juga ditemukan berhubungan dengan kepercayaan diri remaja sebagai gambar Allah. ${ }^{131}$

\section{Tinjauan Teologis-Alkitabiah: Peran Orang Tua Dalam Perkembangan Iman Remaja}

Dalam bab ini penulis membahas mengenai hubungan antara peran orang tua terhadap iman remaja Kristen melalui tinjauan teologis-alkitabiah. Peran orang tua yang dimaksudkan dalam penelitian ini adalah kelekatan dan dukungan iman orang tua, sedangkan iman remaja Kristen mengacu pada religiositas intrinsik, yang terdiri dari empat dimensi, yaitu pengetahuan, kepercayaan, pengalaman, 641.

${ }^{128}$ Flor dan Knapp, "Transmission and Transaction," ${ }^{129}$ Todd F. Martin, James M. White, dan Daniel
Perlman, "Religious Socialization: A Test of the Chan-
neling Hypothesis of Parental Influence on Adolescent
Faith Maturity," Journal of Adolescent Research 18, no.
2 (2003): 185 , diakses 14 November 2017 , https://doi.
org/10.1177/0743558402250349.
${ }^{130}$ Flor dan Knapp, "Transmission and Transaction,"
640.
${ }^{131}$ Myron R. Chartier and Larry A. Goehner, "A Study
of the Relationship of Parent-Adolescent Communica-
tion, Self-Esteem, and God Image," Journal of Psychol-
ogy \& Theology 4 (1976): 230, diakses 17 Desember 2017,
ATLASerials. 
dan praktik. ${ }^{132}$ Dasar alkitabiah dari keempat dimensi tersebut diambil dari Roma 3:28 (kepercayaan), 1 Timotius 2:4 (pengetahuan), Yohanes 15:4-5 (pengalaman), dan Yakobus 2:26 (praktik).

Paulus mempunyai satu keyakinan bahwa

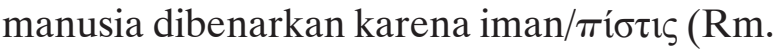
3:28). Iman dalam arti aktif adalah kepercayaan kepada Allah; iman juga berarti percaya dan bergantung kepada Allah. ${ }^{133}$ Dalam Kitab Suci, kata $\pi i ́ \sigma \tau \iota \varsigma$ disebut sebagai iman yang menyelamatkan, ${ }^{134}$ yang selalu mencakup sebuah komponen kognitif, yaitu pengetahuan yang bersandar pada kesaksian para rasul dan para nabi sebagai firman Allah. ${ }^{135}$ Dalam suratnya kepada Timotius, Paulus menyatakan bahwa Allah menghendaki agar semua orang diselamatkan dan memperoleh pengetahuan akan kebenaran (1Tim. 2:4). Kepercayaan dan pengetahuan akan kebenaran membawa seseorang memiliki pengalaman dan relasi nyata dengan Allah dengan cara tinggal di dalam Tuhan, seperti ranting yang melekat dan tinggal di dalam pokoknya (Yoh. 15:4-5). Selanjutnya, pengalaman tinggal di dalam Tuhan akan mendorong seseorang untuk melakukan suatu perbuatan (Yak. 2:26) yaitu menuruti perintah-perintah-Nya (Yoh. 15:10) yang nyata dalam praktik hidup sehari-hari. Dimensi kepercayaan, pengetahuan, dan pengalaman dibahas dalam lingkup relasi pribadi dengan Allah; sedangkan dimensi praktik dibahas sebagai hasil dari relasi dengan Allah, yang dipaparkan berikut ini.

\section{Relasi Pribadi dengan Tuhan}

Kejadian 2:7 menyatakan: "TUHAN Allah membentuk manusia itu dari debu tanah dan menghembuskan (nâphach) napas (neshâmâh) hidup ke dalam hidungnya,

\footnotetext{
${ }^{132}$ Glock, "On the Study," 99.

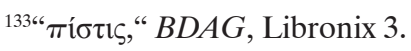

${ }^{134}$ Herman Bavinck, Dogmatika Reformed, jilid 1, Prolegomena, terj. Ichwei G. Indra dan Irwan Tjulianto (Surabaya: Momentum, 2011), 691.

${ }^{135}$ Ibid., 693. demikianlah manusia itu menjadi makhluk hidup (nephesh). Kata nephesh juga digunakan untuk binatang dan manusia (Kej. 1:24, $9: 10,16)$ yang bernapas untuk dapat hidup, ${ }^{136}$ namun manusia mempunyai keunikan dan keistimewaan. Allah membentuk manusia secara pribadi dari debu tanah dan memberikan napas hidup kepadanya sehingga manusia merupakan satu kesatuan fisik dan spiritual. ${ }^{137}$ Oleh karena manusia adalah makhluk spiritual, maka kerinduan spiritual untuk mempunyai relasi dengan Allah selalu menjadi sifat manusia yang tidak dapat dihindarkan. ${ }^{138}$

Sebagai makhluk ciptaan Allah, manusia akan menyia-nyiakan kehidupan dan kehilangan jiwa, jika ia berusaha hidup di dunia tanpa tahu apa pun tentang Allah yang menjadi pemilik dan pemelihara dunia ini. ${ }^{139}$ John Calvin menyebutkan bahwa semua manusia terhubung dengan Allah yang menciptakan mereka, dan hubungan ini sangat terkait dengan cara manusia berpikir dan bertindak. ${ }^{140}$ Relasi dengan Allah merupakan kebutuhan manusia yang akan memberi dampak terhadap seluruh kehidupannya.

Relasi Allah dengan manusia dimulai sejak manusia diciptakan. Keintiman hubungan Allah dan manusia dinyatakan di dalam Kejadian 2. ${ }^{141}$ Keintiman ini menjadi rusak ketika manusia melanggar perintah Allah dan makan

\footnotetext{
${ }^{136}$ Gordon J. Wenham, Genesis 1-15, Word Biblical Commentary 1 (Dallas: Word, 2002), 24, Libronix 3.

${ }^{137}$ Bob Utley, How It All Began: Genesis 1-11, Study Guide Commentary Series Old Testament, vol. 1A (Marshall: Bible Lessons International, 2001), 45, Libronix 3.

${ }^{138}$ Mark R. McMinn dan Clark D. Campbell, Integrative Psychotherapy: Toward a Comprehensive Christian Approach (Downers Grove: IVP Academic, 2007), 25.

${ }^{139}$ J.I. Packer, Knowing God: Tuntunan Praktis untuk Mengenal Allah, terj. Johny The (Yogyakarya: Andi Offset, 2009), 5.

${ }^{140} \mathrm{~K}$. Scott Oliphint, "Pengetahuan yang Utama dan Sederhana (Institutes I.1-5)," dalam Penuntun ke dalam Theologi Institutes Calvin, ed. David W. Hall dan Peter A. Lillback, terj. Lanna Wahyuni (Surabaya: Momentum, 2008), 22.

${ }^{141}$ Mark J. Boda, "Old Testament Foundations of Christian Spirituality," dalam Dictionary of Christian Spirituality,
} 
buah pengetahuan baik dan jahat yang dilarang sehingga Allah mengusir mereka dari taman Eden (Kej. 3:23-24). Namun dalam anugerah-Nya, Allah mencari dan memulihkan persekutuan-Nya dengan umat yang telah meninggalkan dan kehilangan Dia. ${ }^{142}$ Kasih Allah yang besar kepada dunia yang berdosa dan memberontak adalah alasan akan inkarnasi dan kematian Kristus, ${ }^{143}$ agar mereka yang percaya kepada Yesus Kristus tidak binasa melainkan beroleh hidup yang kekal (Yoh. 3:16). Hanya melalui pengorbanan Yesus Kristus, yang adalah Allah dan bersama-sama dengan Allah; dalam arti "hadir" (bdk. Mrk. 6:3) atau "dalam persekutuan dengan Allah" (1Yoh. 1:2-3), atau "dalam kesatuan dengan Allah,"144 manusia bisa mempunyai relasi dengan Allah kembali. Hal ini dapat terjadi melalui kelahiran baru.

Yesus berkata kepada Nikodemus bahwa jika seorang tidak dilahirkan kembali (öv $\omega \theta \varepsilon v$ ), ia tidak dapat melihat Kerajaan Allah (Yoh. 3:3). Kata ö $v \omega \theta \varepsilon v$ bermakna "dari atas." 145 Lebih lanjut Yesus berkata bahwa kelahiran dari atas adalah kelahiran dari air dan Roh (Yoh. 3:5), yang dapat diartikan sebagai kelahiran ilahi atau benih spiritual. ${ }^{146}$ Kelahiran baru dapat terjadi melalui iman atau percaya kepada Yesus Kristus, Anak Allah (Yoh. 3:15, 16:36) yang tidak hanya memulihkan relasi manusia dengan Allah, tetapi juga memberinya status baru sebagai anak-anak Allah (Yoh 1:12).

Calvin mengatakan bahwa iman bukan hanya menerima dan menyetujui (assensus), tetapi

ed. Glenn G. Scorgie (Grand Rapids: Zondervan, 2011), 40.

${ }^{142}$ Bavinck, Dogmatika Reformed, 415.

${ }^{143}$ George R. Beasley-Murray, John, Word Biblical Commentary 36 (Dallas: Word, 2002), 51, Libronix 3.

${ }^{144}$ Ibid., 10.

${ }^{145}$ Friedrich Büchsel, Theological Dictionary of the New Testament I, ed. Gerhard Kittel dan Gerhard Friedrich, terj. Geoffrey G. Bromiley (Grand Rapids: Eerdmans, 1964), 378, Libronix 3.

${ }^{146}$ Gary M. Burge, John, NIV Application Commentary (Grand Rapids: Zondervan, 2000), 115, Libronix 3. juga termasuk pengetahuan (notitia) dan komitmen untuk percaya (fiducia). ${ }^{147}$ Relasi dengan Allah dimulai dengan pengetahuan atau pengenalan akan Allah, namun pengenalan akan Allah yang benar merupakan kasih karunia, yang seluruh inisiatifnya dimulai dari Allah, ${ }^{148}$ sebab tidak ada pengetahuan tentang Allah yang mungkin, kecuali yang keluar dari dan oleh Allah (Mat. 11:27, 1Kor. 2:10). ${ }^{149}$ Allah menyatakan diri-Nya kepada semua ciptaan-Nya melalui wahyu umum dan wahyu khusus. Wahyu umum membuat orang mengetahui tentang Allah, sedang wahyu khusus membuat orang datang kepada Allah secara pribadi. ${ }^{150}$ Di dalam wahyu khusus, Allah menyatakan diri-Nya kepada umat-Nya di dalam diri Yesus Kristus. ${ }^{151}$

Konsep iman selain pengetahuan (notitia) adalah assensus, yang mengacu pada persetujuan intelektual atau penerimaan akan kebenaran teologis. Tidak cukup bagi seseorang untuk percaya pada apa yang tidak dia pahami secara implisit sebab dia membutuhkan pengetahuan yang eksplisit tentang kebenaran Allah. ${ }^{152}$ Iman bukan hanya mengetahui (notitia) dan memahami (assensus) dengan benar apa yang dipercayai, tetapi juga melakukan (fiducia) atau mempraktikkan apa yang dipercayai. ${ }^{153}$ Sama seperti pengetahuan akan Allah menghasilkan ketaatan, iman yang benar juga menghasilkan ketaatan untuk melakukan kehendak Tuhan.

Paulus mengatakan kepada jemaat di Kolose bahwa mereka yang telah menerima Kristus

${ }^{147}$ Joel R. Beeke, Puritan Reformed Spirituality (Darlington: Evangelical, 2006), 34.

${ }^{148}$ Packer, Knowing God, 35.

${ }^{149}$ Bavinck, Dogmatika Reformed, 251.

${ }^{150}$ N.H. Gootjes, "General Revelation in its Relation to Special Revelation," Westminster Theological Journal 51 (1989): 365, diakses 3 Juli 2017, ATLASerials.

${ }^{151}$ Ibid.

${ }^{152}$ John Calvin, Institutes of the Christian Religion, terj. John Allen (Bellingham: Logos Research Systems, 2010), 2:13, Libronix 3.

${ }^{153}$ Rahmiati Tanudjaja, Kuliah Teologi Sistematika (Malang: SAAT, 2014). 
Yesus, Tuhan, hendaklah hidup tetap di dalam Dia (Kol. 3:6). Apa yang ditulis oleh Paulus itu merujuk pada apa yang dikatakan oleh Yesus tentang "tinggal di dalam Kristus," seperti ranting yang tinggal melekat pada pokok anggur (Yoh. 15:1-5). Manusia yang sudah menjadi ciptaan baru seharusnya mempunyai kehidupan yang tinggal di dalam Kristus, dan Kristus dapat mengomunikasikan kepada manusia apa yang sudah diterima-Nya dari Bapa. ${ }^{154}$ Relasi ini merupakan kebutuhan pertama dan utama serta menunjukkan adanya pengalaman dan persekutuan yang erat dengan Allah. Melalui relasi ini pula, umat percaya dapat berjumpa dan berkomunikasi secara pribadi dengan Allah, melalui firman Tuhan dan doa.

\section{Hasil dari Relasi dengan Tuhan}

Menjadi anak Allah adalah sebuah hak istimewa yang bermakna individu menyandang nama Yesus. ${ }^{155}$ Pada saat Allah mengadopsi manusia yang percaya kepada Yesus menjadi anak-anak-Nya, ada sebuah kondisi yang harus dipenuhi sebagai ikatan atas adopsi tersebut, yaitu harus menampakkan kehidupan yang meniru Kristus. ${ }^{156}$ Paulus mengatakan bahwa mereka yang dipilih-Nya, ditentukanNya dari semula untuk menjadi serupa dengan gambaran Anak-Nya (Rm. 8:29). Kelahiran baru bukan hanya mengubah kehidupan internal seseorang, tetapi juga kehidupan eksternal yang dinyatakan melalui kehidupan seseorang di dalam masyarakat. Pengakuan bahwa Kristus adalah Tuhan akan menghasilkan buah yang dapat dilihat oleh orang lain. Kehidupan saleh baik secara pribadi maupun dalam kegiatan ritual bersama orang lain adalah buah yang dihasilkan oleh anak Tuhan.

Kesalehan hidup anak-anak Tuhan dinyatakan dalam ibadahnya kepada Tuhan. Kata "ibadah" dalam PB mempunyai beberapa arti,

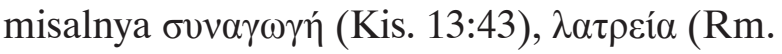

\footnotetext{
${ }^{154}$ Calvin, Institutes of the Christian, 2:5.

${ }^{155}$ Andreas J. Köstenberger, John, Baker Exegetical Commentary on the New Testament (Grand Rapids: Baker Academic, 2004), 38, Libronix 3.

${ }^{156}$ Calvin, Institutes of the Christian Religion, 2:161-162.
}

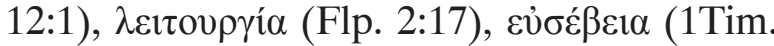
3:16). Dari beberapa arti tersebut penulis menyimpulkan ada dua macam bentuk ibadah, yaitu ibadah dalam bentuk penyembahan (ritual keagamaan) untuk membangun relasi dengan Allah dan ibadah yang mengacu pada kehidupan yang benar dan kudus dalam hidup sehari-hari. ${ }^{157}$

Dalam Perjanjian Lama (PL), Allah menekankan pentingnya ibadah untuk memperingati keluarnya bangsa Israel dari Mesir (Kel. 12:25) dan ibadah di dalam Kemah Pertemuan (Kel. 30:16). Kata yang dipakai adalah ăbôdâh yang dalam PL selalu mengacu pada penyembahan di dalam bait Allah yang merupakan titik pusat ibadah dalam arti umum, yaitu ketaatan pada perintah-perintah Tuhan dan pengabdian kepada-Nya. ${ }^{158}$ Di PB pemakaian kata ibadah dapat memiliki beberapa arti, yaitu dikaitkan dengan tempat ibadah (Kis. 13:43) dan sikap dalam beribadah (Kis. $8: 27,24: 11)$.

Dalam beberapa suratnya kepada Timotius, Paulus sering menggunakan kata ibadah

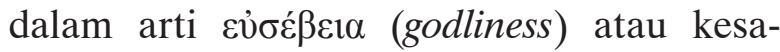
lehan/kekudusan (1Tim. 4:7). Pengenalan akan Allah seharusnya membuat orang mempunyai sikap yang benar terhadap Allah dan melakukan apa yang Dia kehendaki, yaitu kesalehan hidup. ${ }^{159}$ Kesalehan hidup dinyatakan ketika seseorang melakukan perintah Tuhan, misalnya perintah untuk mengabarkan Injil (Mat. 28:19-20), perintah untuk hidup kudus (1Ptr. 1:16), dan perintah untuk mengasihi (Yoh. 13:34).

Kata "ibadah" juga dikaitkan dengan pela-

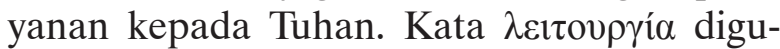
nakan untuk pelayanan para imam dan orang Lewi di dalam dan di tempat kudus, terutama pelayanan para imam di altar. ${ }^{160}$ Pelayanan

${ }^{157}$ Alfius Areng Mutak, "Disiplin Rohani sebagai Praktek Ibadah Pribadi," Jurnal Teologi Aletheia 18, no. 10 (2016): 8 .

\footnotetext{
${ }^{158}$ Mutak, "Disiplin Rohani,” 15.

${ }^{159}$ Beeke, Puritan Reformed Spirituality, 2.

${ }^{160}$ Hermann Strathmann, Theological Dictionary of the New Testament IV, ed. Gerhard Kittel dan Gerhard
} 
para imam adalah pelayanan yang memberikan seluruh hidupnya untuk melayani Tuhan (Ul. 18:5). Sedangkan $\lambda \alpha \tau \rho \varepsilon i ́ \alpha$ mempunyai arti bekerja atau melayani yang mempunyai signifikansi dengan pelayanan agama, khususnya kepada Allah, ${ }^{161}$ dan juga dapat berarti seseorang yang memberikan seluruh hidupnya. ${ }^{162}$

Paulus menggunakan kata $\lambda \varepsilon ı \tau o v \rho \gamma i ́ \alpha$ dalam kaitan dengan korban dan ibadah iman (Flp. 2:17); dan $\lambda \alpha \tau \rho \varepsilon i ́ \alpha$ yaitu ibadah yang berarti mempersembahkan diri sebagai korban yang hidup (Rm. 12:1). Iman kepada Allah akan menghasilkan sikap mau berkorban, seperti yang ditunjukkan oleh jemaat Filipi yang memberi lebih dari kemampuannya (2Kor. 8:2). ${ }^{163}$ Ibadah yang benar bukan hanya secara liturgis dan ritual saja, tetapi berarti mempersembahkan seluruh tubuh dan apa pun yang dilakukan setiap hari kepada Tuhan, ${ }^{164}$ sebuah ibadah yang diungkapkan dalam realitas kehidupan sehari-hari. ${ }^{165}$

\section{Peran Orang Tua dalam Pertumbuhan Iman Remaja}

Orang tua mempunyai peran penting untuk memperkenalkan konsep tentang Tuhan dan iman pada anak-anak mereka sejak bayi. Allah secara khusus memberi perintah pada orang tua untuk mengajarkan tentang perintah dan ketetapan-ketetapan Allah kepada anak-anaknya (Ul. 6:4-9).

Di dalam Alkitab Allah menggambarkan diriNya sebagai seorang ayah yang mendukung umat-Nya Israel, sampai tiba di Tanah Perjanjian (Ul. 1:31). Allah juga digambarkan

Friedrich, trans. Geoffrey G. Bromiley (Grand Rapids: Eerdmans, 1967), 221, Libronix 3.

${ }^{161}$ Ibid., 60.

${ }^{162}$ William Barclay, The Letter to the Romans, New Daily Study Bible, ed. ke-3 (Louisville: Westminster John Knox, 2002), 185, Libronix 3.

${ }^{163}$ Gerald F. Hawthorne, Philippians, Word Biblical Commentary 43 (Dallas: Word, 2004), 148, Libronix 3.

${ }^{164}$ Barclay, The Letter to the Romans, 185.

${ }^{165}$ James D.G. Dunn, Romans 9-16, Word Biblical Commentary 38B (Dallas: Word, 2002), 711, Libronix 3. seperti seorang ibu yang mengasihi anaknya (Yes. 49:15) dan yang menghibur anaknya (Yes. 66:13). Allah digambarkan bukan hanya mengasihi, mendukung, dan memelihara tetapi juga mendisiplin mereka yang dikasihinya (Ibr. 12:5-9). Relasi antara Allah dan umat yang dikasihi-Nya adalah model relasi yang seharusnya dimiliki oleh orang tua terhadap anak-anaknya, yaitu relasi yang dibangun atas dasar kasih dan disiplin, yang akan memimpin pada kebenaran. ${ }^{166}$

Orang tua mengemban dua peran penting, yaitu mengasihi dan mendidik anak-anaknya di dalam Tuhan. Peran orang tua untuk mengasihi anak-anaknya ditunjukkan dengan cara peduli pada kehidupan anak-anaknya, memberi kehangatan kepada anak, dan menghargai anak. Kepedulian orang tua kepada anak-anaknya menjadi nyata ketika orang tua menyediakan dengan tepat apa yang dibutuhkan anak-anak mereka seharihari (Mat. 7:9-10), menyediakan dukungan untuk anak-anaknya dan mencari nafkah untuk mereka (2Kor. 12:14), serta peduli dengan perasaan anaknya (Yes. 49:15, Kol. 3:21). Kehangatan dan kedekatan dirasakan oleh anak ketika ia melihat orang tuanya siap sedia memberikan penghiburan (Yes. 66:13), perlindungan (Ams. 14:26), dan tangan yang terbuka untuk menerima dan mendukungnya (Mzm. 14:6, 46:1, 59:16; Yer. 16:19; Yes. 4:6, 25:4). ${ }^{167}$ Orang tua yang mengasihi Allah akan mengasihi anaknya seperti mengasihi diri sendiri dan menghargai mereka sebagai sesama manusia ciptaan Allah (Mat. 22:39).

Peran orang tua untuk mendidik anak-anaknya dilakukan melalui mengajar, mendisiplin, dan memberi teladan. Perintah Tuhan kepada orang tua untuk mengajar anak-anak mereka terdapat di dalam Ulangan 6:7-9. Orang tua harus mengajarkan dengan tekun kepada anak-anak bahwa Tuhan adalah Allah yang Esa, dan mereka harus mengasihi Tuhan dengan segenap hati, segenap jiwa, dan segenap kekuatan (Ul. 6:4-5). Kasih akan

\footnotetext{
${ }^{166}$ Kim, "Parenting Styles and Children's Spiritual Development," 245.

${ }^{167}$ Kirkpatrick, Attachment, Evolution, 82.
} 
memotivasi disiplin, seperti yang dikatakan Salomo, yaitu siapa mengasihi anaknya akan menghajar dia pada waktunya (Ams. 13:24). Kata "menghajar" (mûsâr) mempunyai arti menghukum, mendisiplin, mengoreksi, memberi peringatan, menegur, memarahi pada waktunya. Tujuan disiplin dari orang tua adalah untuk kebaikan, yaitu agar anak belajar, mengerti dan mengubah perilakunya, supaya pada masa tuanya ia tidak hidup menyimpang (Ams. 22:6). Orang tua juga memberikan contoh kepada anak-anaknya agar mereka mengikuti teladannya. Pengalaman dan perubahan yang dialami oleh orang tua di dalam pengenalannya akan Tuhan akan menjadi modal yang baik ketika mereka mengajarkan kepada anak-anak, sebab anak belajar melalui apa yang dilihat dan dialaminya. ${ }^{168}$

Peran orang tua yang mengasihi dan mendidik anak-anak sejak masih kecil untuk takut akan Tuhan mempunyai peran penting dalam perkembangan iman remaja sehingga mereka dapat mengatasi krisis identitas iman yang terjadi pada masa remaja tersebut. Orang tua yang mengikuti prinsip alkitabiah dalam membesarkan anak akan melihat efek positif pada karakter mereka. Anak-anak yang tumbuh dalam keluarga yang menghormati Kristus lebih cenderung tetap setia kepada Kristus di masa dewasa dibandingkan dengan anak-anak yang orang tuanya mencemarkan nama Tuhan. ${ }^{169}$

Orang tua dapat membantu perkembangan iman remaja yang disesuaikan dengan masa perkembangan mereka yang bercirikan keinginan untuk mandiri dan dipercaya oleh orang tua. Ada empat hal yang dapat dilakukan orang tua, yaitu berpartisipasi dengan remaja dalam kegiatan dan ritual religius sebagai keluarga (misalnya ke gereja, berdoa dan membaca Alkitab bersama); mendorong komunikasi dan diskusi dua arah; memberi contoh kehidupan spiritual yang kongruen

\footnotetext{
${ }^{168}$ Ivy Beckwith, Postmodern Children's Ministry (Grand Rapids: Zondervan, 2004), 48.

${ }^{169}$ Ibid.
}

di hadapan remaja; dan mengasuh mereka dengan penuh kasih tetapi juga tegas. ${ }^{170}$

\section{METODOLOGI PENELITIAN}

Penelitian ini adalah untuk mengukur hubungan antarvariabel, oleh sebab itu pendekatan yang paling baik digunakan adalah metode yang bersifat kuantitatif. Proses penghitungan data dilakukan dengan menggunakan program SPPS, dan Spearman Rank Correlation diterapkan untuk menganalisis derajat atau kekuatan serta arah hubungan antarvariabel. ${ }^{171}$ Teknik pengumpulan data berupa survei dan data dikumpulkan melalui kuesioner yang diberikan kepada responden untuk dijawab sendiri. ${ }^{172}$ Jenis kuesioner yang digunakan adalah kuesioner tertutup, yaitu jawaban atas pernyataan yang diberikan kepada responden diberikan dalam bentuk pilihan (penerapan skala Likert). ${ }^{173}$ Subjek dalam penelitian ini adalah remaja laki-laki dan perempuan dengan rentang usia 13-18 tahun yang menghadiri Kebaktian Remaja di GKA Gloria di Surabaya, yaitu GKA Pacar, GKA Satelit, GKA Rungkut, GKA Galaxy, dan GKA Nirwana.

Langkah pertama yang dilakukan adalah menerjemahkan ketiga alat ukur yang digunakan ke dalam Bahasa Indonesia. Penerjemahan alat ukur melewati beberapa tahap yang dilakukan oleh empat dosen psikologi dan pendidikan Kristen STT SAAT Malang. Setelah itu mengujicobakan kepada sepuluh remaja usia lima belas tahun di GKI Pregolan Bunder Surabaya, dan juga kepada tiga puluhan mahasiswa teologi tingkat satu STT

\footnotetext{
${ }^{170}$ Kevin E. Lawson, "How Parents Nurture the Spiritual Development of their Children," dalam Understanding Children's Spirituality (Eugene: Cascade, 2012), 199.

${ }^{171}$ Neil J. Salkind, Statistics for People Who (Think They) Hate Statistics (London: Sage, 2005)., 270.

${ }^{172}$ Restu Kartiko Widi, Asas Metodologi Penelitian: Sebuah Pengenalan dan Penuntun Langkah demi Langkah Pelaksanaan Penelitian (Yogyakarta: Graha Ilmu, 2010), 85.

${ }^{173}$ Syofian Siregar, Statistika Deskriptif untuk Penelitian: Dilengkapi Perhitungan Manual dan Aplikasi SPSS Versi 17 (Jakarta: RajaGrafindo Persada, 2014), 133.
} 
SAAT Malang. Masukan yang diperoleh dari uji coba tersebut menjadi pertimbangan untuk merevisi ulang kalimat-kalimat yang sulit dimengerti. Hasil uji coba menyatakan bahwa hasil terjemahan alat ukur dapat digunakan untuk penelitian terhadap remaja. Langkah kedua adalah mendapatkan izin dari lima GKA Gloria yang menjadi subjek penelitian, dan selanjutnya penulis berkoordinasi dengan pembimbing remaja gereja setempat untuk melakukan pengumpulan data pada hari Minggu setelah kebaktian remaja di gereja setempat. Langkah ketiga adalah pengumpulan data, yang kemudian diberi kode dan dipilah. Data yang tidak dapat digunakan adalah data yang tidak mencantumkan tanggal lahir responden, dan data yang tidak diisi dengan lengkap (maksimal yang tidak diisi pada masing-masing alat ukur adalah dua item). Langkah terakhir, penulis mengolah data yang dapat digunakan dengan bantuan SPSS untuk menguji hipotesis dan melihat apakah terdapat korelasi antara variabel dependen dan variabel independen.

Dalam penelitian ini ada dua variabel independen, yaitu kelekatan dan dukungan iman orang tua; dan satu variabel dependen, yaitu religiositas. Agar konsep variabel tersebut dapat diukur, maka harus dijelaskan dalam bentuk definisi konseptual dan definisi operasional, yaitu definisi yang didasarkan pada sifat-sifat yang dapat diukur dan diamati. ${ }^{174}$

Kelekatan adalah ikatan perasaan yang kuat, yang menyebabkan figur kelekatan tidak dapat ditukar atau diganti dengan yang lain. ${ }^{175}$ Dalam penelitian ini, remaja yang mengalami kelekatan berarti mempunyai ikatan perasaan yang kuat kepada orang tua. Hal ini ditunjukkan dengan skor total yang tinggi dalam Inventory of Parent and Peer Attachment.

Dukungan iman orang tua adalah proses sosialisasi iman yang diberikan orang tua melalui

\footnotetext{
${ }^{174}$ Sumadi Suryabrata, Restu Kartiko Widi, Asas Metodologi Penelitian: Sebuah Pengenalan dan Penuntun Langkah demi Langkah Pelaksanaan Penelitian (Yogyakarta: Graha Ilmu, 2010), 85.

${ }^{175}$ Ainsworth, "Attachments Beyond Infancy," 711.
}

model iman dan dialog iman. ${ }^{176}$ Dalam penelitian ini, dukungan iman orang tua secara operasional adalah persepsi remaja terhadap proses internalisasi nilai, sikap dan perilaku agama yang dilakukan orang tua dengan cara model iman dan dialog iman. Keberadaan dukungan iman orang tua ditunjukkan dengan skor yang tinggi dalam Perceived Faith Support from Parents and Friends.

Religiositas intrinsik adalah motivasi untuk mengalami dan menjalani kepercayaan religius demi keimanan itu sendiri; tanpa adanya penguatan eksternal. ${ }^{177}$ Dalam penelitian ini, religiositas intrinsik yang dimaksud adalah motivasi seseorang untuk mengetahui (pengetahuan), memercayai (kepercayaan/iman), mengalami (pengalaman), dan mempraktikkan kepercayaan agamanya demi keimanan itu sendiri tanpa adanya penguatan eksternal. Hal ini ditunjukkan dengan skor yang tinggi dalam Intrinsic/Extrinsic Revised Scale.

\section{Alat Ukur Penelitian}

Penelitian ini menggunakan tiga alat ukur, yaitu Inventory of Parent and Peer Attachment untuk mengukur kelekatan remaja kepada orang tua, Perceived Faith Support from Parents and Friends untuk mengukur persepsi remaja terhadap dukungan iman orang tua, dan Intrinsic/Extrinsic Revised Scale untuk mengukur religiositas intrinsik remaja.

Inventory of Parent and Peer Attachment dikembangkan pertama kali oleh Gay C. Armsden dan Mark T. Greenberg. ${ }^{178}$ Untuk penelitian ini digunakan skala IPPA yang sudah disederhanakan oleh Nada Raja dkk. menjadi dua belas item, yang diambil dari empat item dengan koefisien korelasi tertinggi ( $>0.40)$, dari tiga subskala, yaitu trust, communication, dan alienation, untuk orang tua dan teman sebaya secara terpisah. ${ }^{179}$ Pertanyaan dija-

\footnotetext{
${ }^{176}$ Schwartz, "Transformations in Parent," 314.

${ }^{177}$ Gorsuch, “Toward Motivational Theories,” 317.

${ }^{178}$ Widi, Asas Metodologi Penelitian, 85.
}

${ }^{179}$ Shyamala Nada Raja, Rob Mcgee, dan Warren R. Stanton, "Perceived Attachments of Parents and Peers and 
wab dengan pengisian skor yang didasarkan pada skala Likert, dengan lima dimensi pengukuran, yaitu hampir tidak atau sama sekali tidak benar, sedikit benar, kadang-kadang benar, sering kali benar, dan hampir selalu atau selalu benar. Reliabilitas untuk orang tua 0.82 dan untuk teman sebaya $0.80 .{ }^{180}$ Validitas instrumen ini telah diuji hubungannya dengan beberapa hal terkait, misalnya kesejahteraan psikologi, lingkungan keluarga, dan pencarian dukungan dari orang penting lainnya. ${ }^{181}$ Sebelum menghitung total nilai kelekatan, terlebih dahulu dibuat skor terbalik untuk item nomor 4, 7, dan semua item alienation (9-12).

Alat ukur Perceived Faith Support from Parents and Friends (PFS-P dan PFS-F) dibuat oleh Schwartz. Instrumen ini mengukur faith dialogue (dialog iman) dan faith modeling (model iman), yang masing-masing mempunyai empat item pertanyaan. Responden menjawab delapan pertanyaan untuk ibu dan delapan pertanyaan untuk ayah, dengan menggunakan skala Likert dalam empat dimensi pengukuran, yaitu tidak pernah, jarang, kadang-kadang, dan sering. Sedangkan delapan pertanyaan untuk teman tidak dihitung, karena tidak diperlukan dalam penelitian ini. Reliabilitas masing-masing subskala cukup tinggi, yaitu faith dialogue dengan orang tua 0.86 dan faith modeling dengan orang tua 0.90. Penghitungan nilai dukungan iman ayah diukur dengan menjumlahkan skor item 1-8, dan dukungan iman ibu diukur dengan menjumlahkan skor item 9-16.

Skala tentang religiositas intrinsik dan ekstrinsik yang dibuat oleh Allport dan J. Michael Ross disebut Religious Orientation

Psychological Well-Being and Adolescence," Journal of Youth and Adolescence 21, no. 4 (1992): 475.

${ }^{180}$ Ibid.

${ }^{181}$ Gay C. Armsden dan Mark T. Greenberg, "The Inventory of Parent and Peer Attachment: Individual Differences and Their Relationship to Psychological Well-Being in Adolescence," Journal of Youth and Adolescence 16, no. 5 (1987): 435, diakses 15 November 2017, http://dx.doi. org/10.1007/BF02202939.
Scale (ROS), dan terdiri dari 20 pertanyaan. ${ }^{182}$ Dalam perkembangan selanjutnya Gorsuch dan Susan E. McPherson kemudian memberi nama Intrinsic/Extrinsic Revised Scale, yang mengukur religiositas intrinsik (delapan pertanyaan) dan religiositas ekstrinsik (enam pertanyaan). ${ }^{183}$ Dalam penelitian ini hanya religiositas intrinsik yang diukur dan digunakan. Pengisian skala didasarkan pada skala Likert dengan enam dimensi pengukuran, yaitu: sangat tidak setuju, cukup tidak setuju, agak tidak setuju, agak setuju, cukup setuju, dan sangat setuju. Meskipun Gorsuch menggunakan lima dimensi pengukuran, penggunaan enam dimensi pengukuran ini juga dapat diterima. ${ }^{184}$

Reliabilitas untuk item intrinsik sebesar 0.82$0.83 .{ }^{185} \mathrm{I} / \mathrm{E}$-Revised Scale mempunyai sifat psikometrik yang kuat, dan dipertimbangkan sebagai alat ukur yang terbaik untuk mengukur orientasi religius. ${ }^{186}$ Oleh karena skala awal yang dipakai sebelum revisi ini adalah dari The Age Universal I-E Scale yang dapat digunakan untuk anak mulai SD kelas 5 sampai dewasa, ${ }^{187}$ maka Intrinsic/Extrinsic Revised Scale yang dipakai dalam penelitian ini juga dapat digunakan untuk remaja. ${ }^{188}$

Perhitungan nilai intrinsik dilakukan dengan terlebih dahulu memberi skor terbalik untuk 436 .

${ }^{182}$ Allport dan Ross, "Personal Religious Orientation,"

${ }^{183}$ Ibid.

${ }^{184}$ Ibid., 349.

${ }^{185}$ Ibid., 352.

${ }^{186}$ Peter C. Hill, "Measurement in the Psychology of Religion and Spirituality," dalam Handbook of the Psychology of Religion and Spirituality, ed. Raymond F. Paloutzian dan Crystal L. Park (New York: The Guilford, 2005), 54, Adobe PDF ebook.

${ }^{187}$ Richard L. Gorsuch dan G. Daniel Venable, "Development of an 'Age Universal' I-E Scale," Journal for the Scientific Study of Religion 22, no. 2 (1983): 181, diakses 8 November 2017, ATLASerials.

${ }^{188}$ Richard L. Gorsuch dan Susan E. McPherson, "Intrinsic/Extrinsic Measurement: I/E-Revised and Single-Item Scales, Journal for the Scientific Study of Religion 28, no. 3 (1989): 353, diakses 15 November 2017, http:// dx.doi.org/10.2307/1386745. 
item intrinsik terbalik (I reversed), yaitu item nomor 3, 10, dan 14 dengan ketentuan skor 1 diganti 6, 2 diganti 5, 3 diganti 4, dan sebaliknya. Setelah itu skor yang sudah terbalik tersebut dijumlahkan dengan item intrinsik murni yaitu nomor 1, 4, 5, 7, dan 12. Jumlah total delapan item tersebut akan menjadi nilai religiositas intrinsik remaja.

\section{HASIL PENELITIAN DAN DISKUSI}

\section{Hasil Penelitian}

Dari 291 angket yang dibagikan, terdapat 44 data yang tidak dapat digunakan karena data demografis tidak lengkap, usia di luar batas yang ditentukan, dan pengisian data kuesioner tidak memenuhi syarat dan tidak konsisten. Total 247 remaja (120 perempuan dan 127 laki-laki) yang menjadi subjek penelitian ini mempunyai rentang usia 13-18 tahun, yang paling banyak berusia 17 tahun, yaitu 71 remaja dan 14 tahun berjumlah 54 remaja. Meskipun GKA Gloria adalah gereja Kristen Protestan, dalam kebaktian remaja ada tiga remaja yang beragama Katolik dan satu orang yang bukan Kristen/Katolik. Ada juga remaja yang menuliskan mempunyai ayah yang beragama Katolik 12 orang (4.9\%) dan ibu yang beragama Katolik 7 orang (2.8\%); ayah yang bukan Kristen/Katolik 8 orang (3.2\%) dan ibu yang bukan Kristen/Katolik 5 orang (2\%); dan ayah yang tidak beragama ada 2 orang.

Tabel 1 Hasil Uji Normalitas

\begin{tabular}{|l|c|c|c|}
\hline \multirow{2}{*}{} & \multicolumn{3}{|c|}{ Kolmogorov-Smirnov ${ }^{\mathrm{a}}$} \\
\cline { 2 - 4 } & Statistic & $\mathrm{df}$ & Sig. \\
\hline Religiositas & 0.087 & 247 & 0.000 \\
\hline Kelekatan & 0.099 & 247 & 0.000 \\
\hline $\begin{array}{l}\text { Dukungan } \\
\text { Iman }\end{array}$ & 0.057 & 247 & 0.051 \\
\hline
\end{tabular}

${ }^{a}$ Lilliefors Significance Correction

Hasil uji normalitas pada Tabel 1 menunjukkan hasil $\mathrm{p}<0.05$ untuk variabel religiositas intrinsik dan kelekatan kepada orang tua, yang berarti data tidak terdistribusi normal. Sedangkan variabel dukungan iman hasilnya $\mathrm{p}=0.051$ yang berarti $\mathrm{p}>0.05$ yang berarti data terdistribusi normal. Oleh karena salah satu data tidak terdistribusi normal, maka analisis korelasi yang digunakan adalah analisis nonparametrik Spearman Rank Correlation atau disebut juga Spearman's Rho. ${ }^{189}$

Hasil analisis korelasi dengan menggunakan Spearman Rank Correlation pada Tabel 2 menunjukkan bahwa variabel dependen religiositas terhadap variabel independen kelekatan kepada orang tua dan dukungan iman orang tua menunjukkan hasil $\mathrm{p}<0.01$, yang dapat dilihat di baris sig. (2 tailed). Hasil correlation coefficient menunjukkan adanya tanda dua bintang, yang berarti religiositas dengan kelekatan kepada orang tua dan dukungan iman orang tua berkorelasi secara signifikan. Hasil analisis menunjukkan nilai korelasi religiositas dengan kelekatan kepada orang tua $r=0.316$, dan religiositas dengan dukungan iman orang tua $r=0.345$. Nilai ini bermakna adanya korelasi positif, yaitu semakin tinggi kelekatan kepada orang tua, maka semakin tinggi religiositas; dan semakin tinggi dukungan iman orang tua, maka semakin tinggi religiositas. Dan sebaliknya, yaitu semakin rendah kelekatan kepada orang tua, maka semakin tinggi religiositas; dan semakin rendah dukungan iman orang tua, maka semakin rendah religiositas.

Dengan demikian, kedua hipotesis dalam penelitian ini dapat diterima, yaitu:

1. Ada hubungan antara religiositas remaja dengan kelekatan remaja kepada orang tua di GKA Gloria Surabaya. Semakin tinggi kelekatan remaja kepada orang tua, semakin tinggi religiositas remaja.

2. Ada hubungan antara religiositas remaja dengan dukungan iman orang tua di GKA Gloria Surabaya. Semakin tinggi dukungan iman orang tua, semakin tinggi religiositas remaja.

Hasil uji perbandingan pada Tabel 3 antara kelekatan ayah dan kelekatan ibu dengan menggunakan Wilcoxon Signed Ranks Test

${ }^{189}$ Marija Norušis, IBM SPSS Statistics Base 19 (Upper Saddle River: Prentice Hall, 2010), 72, Adobe PDF ebook. 
Tabel 2 Hasil Korelasi Religiositas dengan Kelekatan kepada Orang Tua dan Dukungan Iman Orang Tua

\begin{tabular}{|c|c|c|c|c|c|}
\hline & & & Religiositas & Kelekatan & Dukungan Iman \\
\hline \multirow{9}{*}{$\begin{array}{l}\text { Spearman's } \\
\text { Rho }\end{array}$} & \multirow{3}{*}{ Religiositas } & \begin{tabular}{|l|} 
Correlation \\
Coefficient \\
\end{tabular} & 1.000 & $0.316^{* *}$ & $0.345^{* *}$ \\
\hline & & \begin{tabular}{|l|} 
Sig. \\
$(2$-tailed $)$
\end{tabular} & & 0.000 & 0.000 \\
\hline & & $\mathrm{N}$ & 247 & 247 & 247 \\
\hline & \multirow{3}{*}{ Kelekatan } & \begin{tabular}{|l|l} 
Correlation \\
Coefficient
\end{tabular} & $0.316^{* *}$ & 1,000 & $0.494^{* *}$ \\
\hline & & \begin{tabular}{|l|} 
Sig. \\
$(2$-tailed $)$
\end{tabular} & 0.000 & & 0.000 \\
\hline & & $\mathrm{N}$ & 247 & 247 & 247 \\
\hline & \multirow{3}{*}{ Dukungan Iman } & \begin{tabular}{|l} 
Correlation \\
Coefficient \\
\end{tabular} & $0.345^{* *}$ & $0.494^{* *}$ & 1,000 \\
\hline & & \begin{tabular}{|l|} 
Sig. \\
$(2$-tailed $)$
\end{tabular} & 0.000 & 0.000 & \\
\hline & & $\mathrm{N}$ & 247 & 247 & 247 \\
\hline
\end{tabular}

${ }^{* *}$ Correlation is significant at the 0.01 level (2-tailed)

Tabel 3 Hasil Uji Perbandingan Kelekatan Ibu dan Kelekatan Ayah

\begin{tabular}{|l|l|c|c|c|}
\hline \multicolumn{2}{|c|}{} & $\mathrm{N}$ & Mean Rank & Sum of Ranks \\
\hline \multirow{4}{*}{$\begin{array}{l}\text { Kelekatan Ibu - } \\
\text { Kelekatan Ayah }\end{array}$} & Negative Ranks & $68^{\mathrm{a}}$ & 111.46 & 7579.00 \\
\cline { 2 - 5 } & Positive Ranks & $158^{\mathrm{b}}$ & 114.38 & 18072.00 \\
\cline { 2 - 5 } & Ties & $21^{\mathrm{c}}$ & & \\
\cline { 2 - 5 } & Total & 247 & & \\
\hline
\end{tabular}

${ }^{a}$ Kelekatan Ibu < Kelekatan Ayah

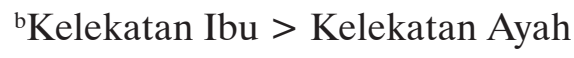

${ }^{\mathrm{c}}$ Kelekatan Ibu = Kelekatan Ayah

\begin{tabular}{|l|c|}
\hline & Kelekatan Ibu - Kelekatan Ayah \\
\hline $\mathrm{Z}$ & $-5,337^{\mathrm{b}}$ \\
\hline Asymp. Sig. (2-tailed) & 0.000 \\
& \\
\hline
\end{tabular}

${ }^{\mathrm{a}}$ Wilcoxon Signed Ranks Test

${ }^{\mathrm{b}}$ Based on negative ranks 
Tabel 4 Hasil Uji Perbandingan Dukungan Iman Ibu dan Dukungan Iman Ayah

\begin{tabular}{|l|l|c|c|c|}
\hline \multicolumn{2}{|c|}{} & $\mathrm{N}$ & Mean Rank & Sum of Ranks \\
\hline \multirow{4}{*}{$\begin{array}{l}\text { Dukungan Iman Ibu }- \\
\text { Dukungan Iman Ayah }\end{array}$} & Negative Ranks & $52^{\mathrm{a}}$ & 63.62 & 3308.00 \\
\cline { 2 - 5 } & Positive Ranks & $147^{\mathrm{b}}$ & 112.87 & 16592.00 \\
\cline { 2 - 5 } & Ties & $48^{\mathrm{c}}$ & & \\
\cline { 2 - 5 } & Total & 247 & & \\
\hline
\end{tabular}

aDukungan Iman Ibu $<$ Dukungan Iman Ayah

${ }^{b}$ Dukungan Iman Ibu $>$ Dukungan Iman Ayah

cDukungan Iman Ibu = Dukungan Iman Ayah

\begin{tabular}{|l|c|}
\hline & Dukungan Iman Ibu - Dukungan Iman Ayah \\
\hline $\mathrm{Z}$ & $-8.186^{\mathrm{b}}$ \\
\hline Asymp. Sig. (2-tailed) & 0.000 \\
\hline
\end{tabular}

${ }^{a}$ Wilcoxon Signed Ranks Test

${ }^{\mathrm{b}}$ Based on negative ranks

menunjukkan adanya perbedaan yang signifikan antara kelekatan ayah dan kelekatan ibu, yang ditunjukkan dengan hasil signifikansi $\mathrm{p}$ $<0.001$. Kelekatan ibu (mean rank $=114.38)$ lebih besar dari kelekatan ayah (mean rank $=$ 111.46).

Hasil uji perbandingan pada Tabel 4 antara kelekatan ayah dan kelekatan ibu dengan menggunakan Wilcoxon Signed Ranks Test menunjukkan adanya perbedaan yang signifikan antara dukungan iman ayah dan dukungan iman ibu, yang ditunjukkan dengan hasil signifikansi $\mathrm{p}<0.001$. Dukungan iman ibu (mean rank $=112.87$ ) lebih besar dari dukungan iman ayah (mean rank $=63.62)$.

\section{Diskusi Hasil Penelitan}

\section{Religiositas dan Kelekatan kepada Orang Tua}

Hasil penelitian mengungkapkan fakta yang sejalan dengan penelitian Pehr Granqvist, yaitu kelekatan aman kepada orang tua akan meningkatkan kemungkinan remaja mengadopsi kepercayaan agama orang tua mereka. ${ }^{190}$ Kelekatan aman dengan orang tua berhubungan dengan kestabilan dan meningkatnya

\footnotetext{
${ }^{190}$ Granqvist, "Attachment and Religiosity," 266.
}

religiositas remaja, ${ }^{191}$ mereka juga dinyatakan tidak mudah mengubah kepercayaan agamanya. ${ }^{192}$ Penelitian Heuikwang Shin menemukan bahwa remaja dengan kelekatan yang aman atau tinggi dengan orang tua menunjukkan hubungan yang aman dan stabil dengan Tuhan. ${ }^{193}$ Hubungan yang hangat dan kepedulian orang tua terhadap remaja juga menjadi salah satu faktor penting bagi mereka untuk terus berkomitmen hadir ke gereja, bahkan bertahan sampai memasuki usia dewasa awal. ${ }^{194}$ Kedekatan dan persahabatan yang dirasakan remaja dengan orang tua juga berhubungan dengan pengertian mereka tentang konsep tentang Tuhan yang dekat, nyata, peduli, dan memaafkan. ${ }^{195}$

Hasil penelitian ini juga menunjukkan bahwa kelekatan dengan ibu lebih tinggi

\footnotetext{
${ }^{191}$ Ibid.

${ }^{192}$ Pehr Granqvist dan Berit Hagekull, "Seeking Security in the New Age: On Attachment and Emotional Compensation," Journal for the Scientific Study of Religion 40, no. 3 (2001): 537.

${ }^{193}$ Shin, “Asian-American College Students,”, 203 49.

${ }^{194}$ Dudley dan Wisbey, “The Relationship of Parenting,"

${ }^{195}$ Kirkpatrick, Attachment, Evolution, 121.
} 
dibandingkan dengan kelekatan ayah. Hal ini sesuai dengan hasil penelitian V.F. Haigler dkk. terhadap 218 siswa laki-laki dan perempuan di Texas. ${ }^{196}$ Penelitian Susan K. Williams dan F. Donald Kelly juga menyatakan bahwa ibu lebih banyak menyediakan waktu bersama dengan remaja dibandingkan ayah, dan kelekatan aman remaja dengan ayah lebih rendah jika dibandingkan dengan ibu. ${ }^{197}$ Janis E. Paterson dkk. menemukan bahwa remaja lebih banyak mencari ibu daripada ayah ketika memerlukan dukungan dan jawaban (baik positif atau negatif) atas peristiwa tertentu. Remaja juga melaporkan kualitas perasaan yang lebih tinggi terhadap ibu daripada ayah. ${ }^{198}$ Kelekatan dengan ibu lebih tinggi daripada kelekatan dengan ayah dapat disebabkan ibu sudah membangun kelekatan dengan anak sejak mereka bayi dan lebih banyak berkomunikasi dengan anak dalam perawatan dan pengasuhan. ${ }^{199}$ Dengan demikian, natur hubungan kelekatan dengan ibu pada masa kanak-kanak dapat memberikan dampak pada religiositas individu. ${ }^{200}$

Ayah dan ibu mempunyai fungsi yang berbeda dalam membangun kelekatan dengan remaja. Kepekaan dan penerimaan ibu yang ditunjukkan ketika mengasuh anak sejak bayi akan menumbuhkan kepercayaan dalam diri remaja, yang menjadi dasar kepercayaan

${ }^{196}$ V.F. Haigler, H.D. Day, dan D.D. Marshall, "Parental Attachment and Gender-Role Identity," Sex Roles 33, no. 3-4 (1995): 213, diakses 14 September 2017, http://dx. doi.org/10.1007/BF01544611.

${ }^{197}$ Susan K. Williams dan F. Donald Kelly, "Relationships Among Involvement, Attachment, and Behavioral Problems in Adolescence: Examining Father's Influence," Journal of Early Adolescence 25, no. 2 (2005): 189, diakses 16 April 2018, http://dx.doi.org/10.1177/0272431604274178.

${ }^{198}$ Janis E. Paterson, Jeff Field, dan Jan Pryor, "Adolescents' Perceptions of Their Attachment Relationships with Their Mothers, Fathers, and Friends," Journal of Youth and Adolescence 23, no. 5 (1994): 593, diakses 14 September 2017, http://dx.doi.org/10.1007/BF01537737.

${ }^{199}$ Chong, "The Impact of Parental," 31.

${ }^{200}$ Lee A. Kirkpatrick dan Phillip R. Shaver, "Attachment Theory and Religion: Childhood Attachments, Religious Beliefs, and Conversion," Journal for the Scientific Study of Religion 29, no. 3 (1990): 324. mereka terhadap hal yang lain. ${ }^{201} \mathrm{Hal}$ ini juga mencakup kepercayaan terhadap orang lain dan diri sendiri, yang membuat remaja mempunyai dasar untuk lebih mandiri. Ibu berperan membangun dasar kepercayaan bagi anak untuk mandiri, sedangkan ayah berfungsi sebagai model peran, yaitu pemimpin yang dapat memberikan nasihat yang rasional dan bermanfaat sehingga remaja dapat mencapai individuasi. ${ }^{202}$

Meskipun religiositas dan kelekatan berkorelasi secara signifikan dan positif, korelasinya termasuk lemah karena berada di kisaran nilai $0.2-0.4 .^{203}$ Hal ini mungkin juga disebabkan oleh keinginan remaja untuk mencari identitas diri. Dengan demikian, mereka akan berusaha untuk mandiri dan lepas dari kelekatan dengan orang tua serta mulai membangun kelekatan dengan teman sebaya. ${ }^{204}$ Dalam tahap perkembangan kognitif, remaja mulai dapat memikirkan hal-hal yang lebih abstrak, yang mengandung idealisme dan kemungkinan-kemungkinan. ${ }^{205}$ Pemikiran tentang orang tua yang ideal akan memberi dampak terhadap penilaian remaja tentang kelekatan dengan orang tua. Selain itu, seiring dengan masa pubertas yang dijalani, remaja juga mengalami pergolakan emosi cukup tinggi, yang ikut berperan ketika remaja diminta untuk menilai kelekatannya kepada orang tua.

\section{Religiositas dan Dukungan Iman Orang Tua}

Hasil penelitian menunjukkan bahwa dukungan iman orang tua berhubungan dengan religiositas. Hal ini senada dengan penelitian Schwartz yang menemukan bahwa orang tua secara signifikan dan positif berkorelasi terhadap religiositas remaja. ${ }^{206}$ Peneli-

${ }^{201}$ Godfrey, Trust of People, Words, 106.

${ }^{202}$ Chong, "The Impact of Parental," 31.

${ }^{203}$ Sylvia Soeherman, Kuliah Statistik (Malang: SAAT, 2015).

${ }^{204}$ Allen, "The Attachment System," 419.

${ }^{205}$ Santrock, Perkembangan Masa Hidup, 423.

${ }^{206}$ Schwartz, "Transformations in Parent," 311. 
tian Wan Ning Bao dkk. juga menunjukkan bahwa orang tua mempunyai peran penting dalam proses transmisi nilai agama kepada anak-anak mereka. ${ }^{207}$ Hasil penelitian tersebut menemukan pentingnya agama, konsep tentang Tuhan, dan kehadiran ibu di gereja yang memberikan dampak, baik pada remaja laki-laki maupun perempuan. Hal ini berarti bahwa apa yang menjadi nilai orang tua, yaitu pentingnya agama dan konsep tentang Tuhan; serta perilaku orang tua yang dilihat melalui kehadirannya di gereja akan diperhatikan dan dinilai remaja yang mendorong mereka untuk mengembangkan religiositasnya.

Hasil penelitian ini juga mendukung penelitian Andrew J. Weigert dan Darwin L. Thomas yang menyebutkan bahwa gabungan dukungan iman dan kontrol orang tua akan memberikan hasil yang cukup konsisten pada identitas religius remaja. ${ }^{208}$ Dalam tahap perkembangan iman, remaja akan berusaha mengidentifikasi dan membentuk imannya secara pribadi dan mandiri, ${ }^{209}$ namun dukungan dan kontrol dari orang tua akan dapat menolongnya. Dukungan dapat diberikan dengan cara memberi kebebasan dan kepercayaan kepada remaja untuk menentukan imannya sendiri dan kontrol diberikan dengan cara berdiskusi dengan remaja tentang hal-hal yang berkaitan dengan iman. Dukungan, kontrol, dan model perilaku dari kedua orang tua akan lebih menunjukkan hasil yang positif, seperti diungkapkan penelitian Leslie J. Francis dan Harry M. Gibson yang menyatakan bahwa remaja cenderung pergi ke gereja ketika didukung oleh contoh dari kedua orang tuanya daripada oleh salah satu orang tua saja. ${ }^{210}$ Penelitian Barry Gane menemukan bahwa $82 \%$ remaja mengakui peran penting orang tua dalam perkembangan iman mereka. ${ }^{211}$

\footnotetext{
${ }^{207}$ Bao, et al., "Perceived Parental Acceptance," 370. 391.

${ }^{208}$ Weigert dan Thomas, "Parental Support, Control,"

${ }^{209}$ Fowler, Stages of Faith, 290.

${ }^{210}$ Francis dan Gibson, "Parental Influence and Adolescent," 248.

${ }^{211}$ Barry Gane, "Adolescent Faith That Lasts," The Journal of Youth Ministry 13, no. 1 (2011): 44.
}

Semakin banyak orang tua berbicara tentang iman mereka, maka semakin tinggi kecenderungan remaja untuk membangun iman dan komitmen Kristen mereka. ${ }^{212}$

Hasil penelitian ini juga menunjukkan bahwa dukungan iman ibu lebih besar dari dukungan iman ayah. Dalam disertasinya, Lynn mengungkapkan bahwa keyakinan ayah akan pentingnya kehadiran dan keterlibatannya di rumah akan menentukan peran ayah dalam kehidupan anak-anak mereka. ${ }^{213}$ Jika ayah mempunyai keyakinan bahwa ia mempunyai peran penting dalam perkembangan anakanak mereka, maka ia akan terlibat lebih banyak dalam kehidupan anak-anak mereka, termasuk juga dalam hal religiositas. Brent $\mathrm{A}$. McBride dkk. menemukan bahwa keyakinan ibu tentang peran ayah berdampak pada keyakinan ayah akan perannya dalam keluarga. ${ }^{214}$ Dengan demikian, ibu yang menginginkan ayah berperan lebih banyak dalam perkembangan iman anak-anaknya dapat menjalankan fungsi sebagai penolong dan memberikan dorongan serta keyakinan bagi ayah akan perannya dalam keluarga.

Penelitian Gane juga menemukan bahwa dukungan iman ibu mempunyai peran yang lebih kuat dibanding dukungan iman ayah, dalam kaitan dengan religiositas, ${ }^{215}$ dan hal ini terjadi baik bagi remaja laki-laki maupun perempuan. ${ }^{216}$ Hal senada juga dikemukakan oleh Bao dkk., yaitu bahwa ibu lebih memberikan dampak jika dibandingkan ayah dalam kepercayaan agama atau religiositas anak. ${ }^{217}$ Faktor yang menjelaskan bahwa dukungan ibu

\footnotetext{
${ }^{212}$ Ibid., 46.

${ }^{213}$ Mark Lynn, "Influences on Father Involvement: Testing for Unique Contributions of Religion and Spirituality" (disertasi, Marquette University, 2009), 9.

${ }^{214}$ Brent A. McBride et al., "Paternal Identity, Maternal Gatekeeping, and Father Involvement," Family Relations 54 (2005): 368, diakses 16 April 2018, http://dx.doi. org/10.1111/j.1741-3729.2005.00323.x.

${ }^{215}$ Gane, "Adolescent Faith That Lasts," 44.

${ }^{216}$ Francis dan Gibson, "Parental Influence and Adolescent," 248.

${ }^{217}$ Bao, et al., "Perceived Parental Acceptance," 370.
} 
lebih tinggi dari ayah adalah karena kualitas hubungan ibu-anak yang penuh kasih, hangat, peka, dan mau bekerja sama umumnya lebih baik daripada ayah. Kualitas relasi seperti hubungan ibu-anak ini berperan terhadap transmisi nilai agama dari orang tua kepada anak. ${ }^{218}$ Hubungan yang hangat dan dekat dengan orang tua akan membuat remaja cenderung untuk memiliki kepercayaan religius yang sama dengan orang tuanya. ${ }^{219}$

Hasil penelitian menunjukkan bahwa dukungan iman orang tua berkorelasi dengan religiositas, namun korelasinya termasuk lemah karena berada di bawah 0.4. Hal ini mungkin terjadi karena remaja sedang berada pada tahap perkembangan moral, yang motivasi utamanya adalah menjadi anak baik dan menyenangkan hati orang-orang yang sangat penting dalam hidupnya, termasuk orang tua, dan berusaha untuk tidak mengecewakan pendapat dan harapan mereka. ${ }^{220}$ Di satu sisi, remaja berusaha menyenangkan orang tua dengan menaati mereka dan mengikuti kepercayaan yang sama dengan orang tua, namun di sisi yang lain mereka berusaha untuk mandiri dan lepas dari kontrol orang tua. Masalah yang mungkin perlu diteliti lebih lanjut adalah apakah hasil religiositas remaja pada penelitian ini muncul karena adanya proses transmisi, yaitu remaja hanya menurut saja apa kata orang tua; atau karena proses transaksional, yaitu adanya proses timbal balik dalam interaksi agama yang membuat remaja dapat mengambil keputusan sendiri.

\section{SARAN}

Berdasarkan hasil penelitian yang telah dipaparkan di atas, penulis memberikan beberapa saran yang dapat dipertimbangkan oleh beberapa pihak terkait. Pertama, perlunya diadakan lokakarya atau seminar untuk memberikan kesadaran akan perubahan yang dialami remaja pada masa pubertas, terkait dengan

\footnotetext{
${ }^{218}$ Taris dan Semin, "Passing on the Faith," 213.

${ }^{219}$ Hoge, Petrillo, dan Smith, "Transmission of Religious," 577.

${ }^{220}$ Fowler, Stages of Faith, 74.
}

perkembangan kognitif, afektif, sosial dan moral.

Kedua, pembina remaja juga dapat membangkitkan minat religius remaja, misalnya dengan mengadakan kelompok baca Alkitab yang membaca 1-2 pasal setiap hari. Pertemuan atau kebaktian orang tua-remaja dalam suasana yang akrab dan dinamis juga dapat menjadi jembatan agar komunikasi orang tua-remaja makin terbuka dan orang tua lebih memahami kehidupan remaja.

Ketiga, orang tua juga disarankan untuk lebih membangun kelekatan dengan anak remajanya melalui komunikasi dua arah dan memberikan kepercayaan kepada mereka. Dalam hal ini gereja atau komisi terkait dengan orang tua dapat membantu dengan mengadakan seminar, misalnya tentang keterampilan berkomunikasi dan bagaimana memberi kepercayaan kepada para remaja. Selain itu, orang tua juga disarankan untuk memberikan dukungan iman kepada remaja melalui dialog iman dan teladan iman. Dialog iman dapat dilakukan dengan mengadakan ibadah keluarga dengan cara yang disesuaikan dengan kehidupan remaja, atau membuat proyek keluarga bersama yang kemudian proses dan hasilnya didiskusikan berdasarkan iman Kristen. Membicarakan tentang kejadian sehari-hari juga dapat dikaitkan dengan iman Kristen, dengan cara yang tidak terkesan menggurui, tetapi justru remaja dapat melihat teladan orang tua dan belajar bagaimana hidup sebagai orang Kristen.

Keempat, kalangan akademik dapat melakukan penelitian lain tentang kelekatan ayah dan ibu dengan remaja, yang dikaitkan dengan peran dan karakter ayah secara khusus, misalnya ayah sebagai pencari nafkah, teman diskusi, dan aktivitas antar jemput anak.

Studi jangka panjang sebagai kelanjutan dari penelitian ini juga dapat dilakukan, khususnya ketika remaja akhir dalam penelitian ini telah memasuki usia dewasa. Tujuannya adalah untuk melihat apa yang menyebabkan religiositas mereka meningkat atau menurun sehingga memberi manfaat lebih mendalam 
bagi gereja. Penelitian kuantitatif dan kualitatif yang melibatkan ayah, ibu, dan remaja, juga akan mendapatkan hasil yang lebih nyata tentang peran orang tua dalam kehidupan religiositas remaja.

\section{DAFTAR KEPUSTAKAAN}

Acock, Alan C., dan Vern L. Bengtson. "On the Relative Influence of Mothers and Fathers: A Covariance Analysis of Political and Religious Socialization." Journal of Marriage and Family 40, no. 3 (1978): 519-530. Diakses 19 Desember 2017. http://dx.doi.org/10.2307/350932.

Ainsworth, Mary S. "Attachments Beyond Infancy." American Psychologist 44, no. 4 (1989): 709-716. Diakses 30 Oktober 2017. http://dx.doi. org/10.1037/0003-066X.44.4.709.

Ainsworth, Mary S. dan John Bowlby. "An Ethological Approach to Personality Development," American Psychologist 46, no. 4 (1991): 338. Diakses 9 November 2017. http://dx.doi. org/10.1037/0003-066X.46.4.333.

Ainsworth, Mary D. Slater, Mary C. Blehar, Everett Waters, dan Sally Wall. Patterns of Attachment: A Psychological Study of the Strange Situation. New York: Psychology Press, 1978.

Allen, Joseph P. "The Attachment System in Adolescence." Dalam Handbook of Attachment: Theory, Research, and Clinical Applications, diedit oleh Jude Cassidy dan Phillip R. Shaver, 419-435. Ed. ke-2. New York: The Guilford, 2008. Adobe PDF ebook.

Allport, Gordon W. "The Religious Context of Prejudice." Journal for the Scientific Study of Religion 5, no. 3 (1966): 447-457. Diakses 3 November 2017. http://dx.doi. org/10.2307/1384172.

Allport, Gordon W., dan J. Michael Ross. "Personal Religious Orientation and Prejudice." Journal of Personality and
Social Psychology 5, no. 4 (1967): 432-443. Diakses 3 November 2017. http://dx.doi. org/10.1037/h0021212.

Armsden, Gay C., dan Mark T. Greenberg. "The Inventory of Parent and Peer Attachment: Individual Differences and Their Relationship to Psychological Well-Being in Adolescence." Journal of Youth and Adolescence 16, no. 5 (1987): 427-454. Diakses 15 November 2017. http://dx.doi. org/10.1007/BF02202939.

Armsden, Gay C., Elizabeth McCauley, Mark T. Greenberg, Patrick M. Burke, dan Jeffrey R. Mitchell. "Parent and Peer Attachment in Early Adolescent Depression." Journal of Abnormal Child Psychology 18, no. 6 (1990): 683-697. Diakses 11 September 2017. http://dx.doi.org/10.1007/ BF01342754.

Bandura, Albert. "Commentary: 'On the Psychosocial Impact and Mechanisms of Spiritual Modeling." International Journal for the Psychology of Religion 13, no. 3 (2003): 167-173. Diakses 14 November 2017. https://doi.org/10.1207/ S15327582IJPR1303_02.

Bao, Wan-Ning, Les B. Whitbeck, Danny R. Hoyt, dan Rand D. Conger. "Perceived Parental Acceptance as a Moderator of Religious Transmission among Adolescent Boys and Girls." Journal of Marriage and the Family 61, no. 2 (1999): 362-374. Diakses 30 Oktober 2017. http://dx.doi. org/10.2307/353754.

Barclay, William. The Letter to the Romans. New Daily Study Bible. Ed. ke-3. Louisville: Westminster John Knox, 2002. Libronix 3.

Bavinck, Herman. Dogmatika Reformed. Jilid 1, Prolegomena. Diterjemahkan oleh Ichwei G. Indra dan Irwan Tjulianto. Surabaya: Momentum, 2011.

Beasley-Murray, George R. John. Word Biblical Commentary 36. Dallas: Word, 2002. Libronix 3. 
Beckwith, Ivy. Postmodern Children's Ministry. Grand Rapids: Zondervan, 2004

Beeke, Joel R. Puritan Reformed Spirituality. Darlington: Evangelical, 2006.

Boda, Mark J. "Old Testament Foundations of Christian Spirituality." Dalam Dictionary of Christian Spirituality, diedit oleh Glenn G. Scorgie, 40-45. Grand Rapids: Zondervan, 2011.

Bonewell, Kelly James. "Intrinsic and Extrinsic Religiosity and Sexual Compulsivity with Christian Males: Understanding Concepts and Correlations Based on Race, Age and Socio-Economic Status and Marital Status." Disertasi, Capella University, 2010. http://www.kellybonewell.com/wp-content/uploads/2010/11/ Intrinsic-and-Extrinsic-Religiosity-and-Sexual-Compulsivity-with-Christian-Males-Understanding-Correlations-and-Concepts-Kelly-James-Bonewell.pdf.

Bowlby, John. Separation: Anxiety, and Anger. Attachment and Loss 2. New York: Basic, 1973. Adobe PDF ebook.

Attachment. Attachment and Loss 1. New York: Basic, 1982. Adobe PDF ebook.

- A Secure Base: Parent-Child Attachment and Healthy Human Development. New York: Basic, 1990. Adobe PDF ebook.

Boyatzis, Chris J. "Religious and Spiritual Development in Childhood." Dalam Handbook of the Psychology of Religion and Spirituality, diedit oleh Raymond F. Paloutzian dan Crystal L. Park, 123-143. New York: The Guilford, 2005. Diakses 20 Oktober 2017. Adobe PDF ebook.

Bradley, Robert H. "Environment and Parenting." Dalam Handbook of Parenting Volume 2 Biology and Ecology of Parenting, diedit oleh Marc H. Bornstein, 281-314. New Jersey: Lawrence Erlbaum Associates, 2002. Adobe PDF ebook.
Bretherton, Inge. "The Origins of Attachment Theory: John Bowlby and Mary Ainsworth." Developmental Psychology 28, no. 5 (1992): 759-775. Diakses 14 November 2017. http://doi.apa.org/getdoi. cfm?doi=10.1037/0012-1649.28.5.759.

Büchsel, Friedrich. Theological Dictionary of the New Testament I. Diedit oleh Gerhard Kittel dan Gerhard Friedrich. Diterjemahkan oleh Geoffrey G. Bromiley. Grand Rapids: Eerdmans, 1964. Libronix 3.

Budijanto, Bambang, ed. Dinamika Spiritualitas Generasi Muda Kristen Indonesia. Jakarta: Bilangan Research Center, 2018.

Burge, Gary M. John. NIV Application Commentary. Grand Rapids: Zondervan, 2000. Libronix 3.

Calvin, John. Institutes of the Christian Religion. Diedit oleh John Allen. Diterjemahkan oleh John Allen. Bellingham: Logos Research Systems, 2010. Libronix 3.

Chartier, Myron R., dan Larry A. Goehner. "A Study of the Relationship of Parent-Adolescent Communication, Self-Esteem, and God Image." Journal of Psychology \& Theology 4 (1976): 227-232. Diakses 17 Desember 2017. ATLASerials.

Chaves, Mark. "Secularization and Religious Revival: Evidence from U.S. Church Attendance Rates, 1972-1986." Journal for the Scientific Study of Religion 28, no. 4 (1989): 464-477. Diakses 19 Desember 2017. http://dx.doi.org/10.2307/1386577.

Chong, Ho Ming. “The Impact of Parental Attachment on Adolescent Externalizing Problem Behaviour in Hong Kong." Department of Applied Social Studies (2007): 1-67. Diakses 11 September 2017. http://lbms03.cityu.edu.hk/oaps/ss20075790-hmc970.pdf.

Clinton, Tim, dan Gary Sibcy. Attachment: Why You Love, Feel and Act the Way You Do. Brentwood: Integrity, 2012. 
Cohen, Adam B., John D. Pierce, Jacqueline Chambers, Rachel Meade, Benjamin J. Gorvine, dan Harold G. Koenig. "Intrinsic and Extrinsic Religiosity, Belief in the Afterlife, Death Anxiety, and Life Satisfaction in Young Catholics and Protestants." Journal of Research in Personality 39, no. 3 (2005): 307-324. Diakses 22 November 2017. https://doi.org/10.1016/j. jrp.2004.02.005.

Collins, W. Andrew, dan Brett Laursen. "Parent-Adolescent Relationships and Influences." Dalam Handbook of Adolescent Psychology, diedit oleh Richard M. Lerner dan Laurence Steinberg, 331-362. Ed. ke-2. New Jersey: John Wiley \& Sons, 2004. Adobe PDF ebook.

Denton, Melinda Lundquist. "Relationship Quality between Parents and Adolescents: Understanding the Role of Religion." Disertasi, University of North Carolina, 2006. https://cdr.lib.unc.edu/ indexablecontent/uuid:b01a41ca-9b484c05-8ecd-3814f8a98cc7.

Donahue, Michael J., dan Peter L. Benson. "Religion and the Well-Being of Adolescents." Journal of Social Issues 51, no. 2 (1995): 145-160. Diakses 23 Oktober 2017. http://dx.doi. org/10.1111/j.1540-4560.1995.tb01328.x.

Dudley, Roger L., dan Randall L. Wisbey. "The Relationship of Parenting Styles to Commitment to the Church among Young Adults." Religious Education 95, no. 1 (2000): 39-50. Diakses 23 Agustus 2017. ATLASerials.

Dunn, James D.G. Romans 9-16. Word Biblical Commentary 38A. Dallas: Word, 2002. Libronix 3.

Ebstyne King, Pamela, dan James L. Furrow. "Religion as a Resource for Positive Youth Development: Religion, Social Capital, and Moral Outcomes." Psychology of Religion and Spirituality 40, no. 5 (2004): $703-$ 713. Diakses 30 November 2017. http:// dx.doi.org/10.1037/0012-1649.40.5.703.
Erikson, Erik H. Childhood and Society. Albury: Imago, 1951. Adobe PDF ebook.

Etzion-Carasso, Ayelet, dan David Oppenheim. "Open Mother-Pre-Schooler Communication: Relations with Early Secure Attachment." Attachment \& Human Development 2, no. 3 (2000): 347-378.

Feist, Jess, dan J. Feist, Gregory. Teori Kepribadian Buku 2. Diterjemahkan oleh Smita Prathita Sjahputri. Jakarta: Salemba Humanika, 2014.

Flor, Douglas L., dan Nancy Flanagan Knapp. "Transmission and Transaction: Predicting Adolescents' Internalization of Parental Religious Values." Journal of Family Psychology 15, no. 4 (2001): 627-645.

Fowler, James W. Stages of Faith: The Psychology of Human Development and The Quest for Meaning. New York: Harper Collins, 1981.

Francis, Leslie J., dan Harry M. Gibson. "Parental Influence and Adolescent Religiosity: A Study of Church Attendance and Attitude Toward Christianity Among Adolescents 11 to 12 and 15 to 16 Years Old." International Journal for the Psychology of Religion 3, no. 4 (1993): 241253. Diakses 17 Desember 2017. ATLA Serials.

Fulton, Aubyn S. "Identity Status, Religious Orientation, and Prejudice." Journal of Youth and Adolescence 26, no. 1 (1997): 1-11. Diakses 29 November 2017. http:// dx.doi.org/10.1023/A:1024519227129.

Gane, Barry. "Adolescent Faith That Lasts." The Journal of Youth Ministry 13, no. 1 (2011): 42-62.

Glock, Charles Young. "On the Study of Religious Commitment." Religious Education 57, no. 4 (1962): 98-110. Diakses 7 November 2017. http://dx.doi. org/10.1080/003440862057S407. 
Godfrey, Joseph J. Trust of People, Words, and God. Notre Dame: University of Notre Dame Press, 2012.

Gootjes, N.H. "General Revelation in its Relation to Special Revelation." Westminster Theological Journal 51 (1989): 359-368. Diakses 3 Juli 2017. ATLASerials.

Gorsuch, Richard L. "Toward Motivational Theories of Intrinsic Religious Commitment." Journal for the Scientific Study of Religion 33, no. 4 (1994): 315-325. Diakses 6 November 2017. http://dx.doi. org/10.2307/1386491.

Gorsuch, Richard L. dan G. Daniel Venable. "Development of an 'Age Universal' I-E Scale." Journal for the Scientific Study of Religion 22, no. 2 (1983): 181-187. Diakses 8 November 2017. ATLASerials.

Gorsuch, Richard L., dan Susan E. McPherson. "Intrinsic/Extrinsic Measurement : I/E-Revised and Single-Item Scales." Journal for the Scientific Study of Religion 28, no. 3 (1989): 348-354. Diakses 15 November 2017. http://dx.doi. org/10.2307/1386745.

Granqvist, Pehr. "Attachment and Religiosity in Adolescence: Cross-Sectional and Longitudinal Evaluations." Personality and Social Psychology Bulletin 28, no. 2 (2002): 260-270. Diakses 30 Oktober 2017. http:// dx.doi.org/10.1177/0146167202282011.

Granqvist, Pehr, dan Berit Hagekull. "Seeking Security in the New Age: On Attachment and Emotional Compensation." Journal for the Scientific Study of Religion 40, no. 3 (2001): 527-545.

Grolnic, Wendy S., Edward L. Deci, dan Richard M. Ryan. "Internationalization within the Family: The Self-Determination Theory Perspective." Dalam Parenting and Children's Internalization of Values: $A$ Handbook of Contemporary Theory, diedit oleh Joan E. Grusec dan Leon Kuczynski, 135-159. New York: Wiley, 1997.
Haigler, V.F., H.D. Day, dan D.D. Marshall. "Parental Attachment and Gender-Role Identity." Sex Roles 33, no. 3-4 (1995): 203-220. Diakses 14 September 2017. http://dx.doi.org/10.1007/BF01544611.

Hawthorne, Gerald F. Philippians. Word Biblical Commentary 43. Dallas: Word, 2004. Libronix 3.

Helms, Sarah W., Michelle Gallagher, Casey D. Calhoun, Sophia Choukas-Bradley, Glen C. Dawson, dan Mitchell J. Prinstein. "Intrinsic Religiosity Buffers the Longitudinal Effects of Peer Victimization on Adolescent Depressive Symptoms." Journal of Clinical Child and Adolescent Psychology 44, no. 3 (2015): 471-479. Diakses 29 November 2017. http://dx.doi.org/10.1 080/15374416.2013.865195.

Hill, Peter C. "Measurement in the Psychology of Religion and Spirituality." Dalam Handbook of the Psychology of Religion and Spirituality, diedit oleh Raymond F. Paloutzian dan Crystal L. Park, 43-61. New York: The Guilford, 2005. Adobe PDF ebook.

Hoeve, MacHteld, Geert Jan J.M. Stams, Claudia E. Van Der Put, Judith Semon Dubas, Peter H. Van Der Laan, dan Jan R.M. Gerris. "A Meta-Analysis of Attachment to Parents and Delinquency." Journal of Abnormal Child Psychology 40, no. 5 (2012): 771-785. Diakses 11 Desember 2017. https://dx.doi.org/10.1007/ s10802-011-9608-1.

Hoge, Dean R., dan Gregory H. Petrillo. "Development of Religious Thinking in Adolescence: A Test of Goldman's Theories." Journal for the Scientific Study of Religion 17, no. 2 (1978): 139-154. Diakses 14 November 2017. http://dx.doi. org/10.2307/1386157.

Hoge, Dean R., Gregory H. Petrillo, dan Ella I. Smith. "Transmission of Religious and Social Values from Parents to Teenage Children." Journal of Marriage and the Family 44, no. 3 (1982): 569-580. 
Diakses 14 November 2017. http://dx.doi. org/10.2307/351580.

Hood, Ralph W., Peter C. Hill, dan Bernard Spilka, The Psychology of Religion, ed. ke-4. New York: Guilford, 2009. Adobe PDF ebook.

Jessor, Shirley L., dan Richard Jessor. "Maternal Ideology and Adolescent Problem Behavior." Developmental Psychology 10, no. 2 (1974): 246-254. Diakses 18 Desember 2017. http://dx.doi.org/10.1037/ h0035991.

Kelland, Mark. "Social Learning Theory and Personality Development." OpenStax-CNX module (1963): 1-25.

Kerestes, Michael, James Youniss, dan Edward Metz. "Longitudinal Patterns of Religious Perspective and Civic Integration." Applied Developmental Science 8, no. 1 (2004): 39-46. Diakses 23 Oktober 2017. http://dx.doi.org/10.1207/ S1532480XADS0801_5.

Kim, Sungwon. "Parenting Styles and Children's Spiritual Development." Dalam Nurturing Children's Spirituality: Christian Perspectives and Best Practices, diedit oleh Holly Catterton Allen, 233-251. Oregon: Cascade, 2008.

King, Pamela Ebstyne, dan Robert R. Roeser. "Religion and Spirituality in Adolescent Development." Dalam Handbook of Adolescent Psychology, diedit oleh Richard M. Lerner dan Laurence Steinberg, 435-478. Ed. ke-3. New Jersey: John Wiley \& Sons, 2009.

Kirkpatrick, Lee A. Attachment, Evolution, and the Psychology of Religion. New York: Guilford, 2005. Adobe PDF ebook.

Kirkpatrick, Lee A., dan Phillip R. Shaver. "Attachment Theory and Religion: Childhood Attachments, Religious Beliefs, and Conversion." Journal for the Scientific Study of Religion 29, no. 3 (1990): 315-334.
Kobak, Roger, dan Stephanie Madsen. "Disruptions in Attachment Bonds: Implications for Theory, Research, and Clinical Intervention." Dalam Handbook of Attachment: Theory, Research, and Clinical Applications, diedit oleh Jude Cassidy dan Phillip R. Shaver, 23-47. Ed. ke-2. New York: The Guilford, 2008. Adobe PDF ebook.

Kochanska, Grazyna. "Emotional Development in Children with Different Attachment Histories: the First Three Years." Child development 72, no. 2 (2001): 474490. Diakses 9 Desember 2017. http:// www.psy.miami.edu/faculty/dmessinger/c_c/rsrcs/rdgs/attach/kochanska_CD_ attach_emot.pdf.

Köstenberger, Andreas J. John. Baker Exegetical Commentary on the New Testament. Grand Rapids: Baker Academic, 2004. Libronix 3.

Lawrence, Jeanette A., dan Jaan Valsiner. "Conceptual Roots of Internalization: From Transmission to Transformation." Human Development 36 (1993): 150-167. Diakses 14 November 2017. http://dx.doi. org/10.1159/000277333.

Leas, Loranie, dan David Mellor. "Prediction of Delinquency: The Role of Depression, Risk-taking, and Parental Attachment." Behaviour Change 17, no. 3 (2000): 155166. Diakses 11 Desember 2017. http:// dx.doi.org/10.1375/bech.17.3.155.

Lawson, Kevin E. "How Parents Nurture the Spiritual Development of their Children." Dalam Understanding Children's Spirituality, 197-222. Eugene: Cascade, 2012.

Lynn, Mark. "Influences on Father Involvement: Testing for Unique Contributions of Religion and Spirituality." Disertasi, Marquette University, 2009.

Maccoby, Eleanor E. "Parenting and its Effects on Children: On Reading and Misreading Behavior Genetics." Annual Review of Psychology 51, no. 1 (2000): 1-27. 
Diakses 19 Oktober 2017. https://www. doi.org/10.1146/annurev.psych.51.1.1.

Martin, Todd F., James M. White, dan Daniel Perlman. "Religious Socialization: A Test of the Channeling Hypothesis of Parental Influence on Adolescent Faith Maturity." Journal of Adolescent Research 18, no. 2 (2003): 169-187. Diakses 14 November 2017. https://doi. org/10.1177/0743558402250349.

McBride, Brent A., Geoffrey L. Brown, Kelly K. Bost, Nana Shin, Brian Vaughn, dan Byran Korth. "Paternal Identity, Maternal Gatekeeping, and Father Involvement." Family Relations 54 (2005): 360372. Diakses 16 April 2018. http://dx.doi. org/10.1111/j.1741-3729.2005.00323.x.

McCullough, Michael E. dan Brian L. B. Willoughby. "Religion, Self-Regulation, and Self-Control: Associations, Explanations, and Implications." Psychological Bulletin 135, no. 1 (2009): 73. Diakses 29 Oktober 2017. http://dx.doi.org/10.1037/a0014213.

McMinn, Mark R., dan Clark D. Campbell. Integrative Psychotherapy: Toward a Comprehensive Christian Approach. Downers Grove: IVP Academic, 2007.

Mowry, Bill J. "A Contextualized/Transactional Model for Leadership Development." Christian Education Journal 13, no. 1 (1992): 61-70. Diakses 17 Desember 2017. ATLA Serials.

Mutak, Alfius Areng. "Disiplin Rohani sebagai Praktek Ibadah Pribadi." Jurnal Teologi Aletheia 18, no. 10 (2016): 1-24.

Norušis, Marija. IBM SPSS Statistics Base 19. New Jersey: Prentice Hall, 2010. Adobe PDF ebook.

Oliphint, K. Scott. "Pengetahuan yang Utama dan Sederhana (Institutes I.1-5)." Dalam Penuntun ke dalam Theologi Institutes Calvin, diedit oleh David W. Hall dan Peter A. Lillback, diterjemahkan oleh Lanna Wahyuni, 17-46. Surabaya: Momentum, 2008
Oman, Doug, dan Carl E Thoresen. "Spiritual Modeling: A Key to Spiritual and Religious Growth?" The International Journal for the Psychology of Religion 13, no. 3 (2003): 149-165. Diakses 31 Oktober 2017. http://dx.doi.org/10.1207/ S15327582IJPR1303_01.

Ozorak, Elizabeth Weiss. "Social and Cognitive Influences on the Development of Religious Beliefs and Commitments in Adolescence." Journal for the Scientific Study of Religion 28, no. 4 (1989): 448463. Diakses 30 November 2017. http:// dx.doi.org/10.2307/1386576.

Packer, J.I. Knowing God: Tuntunan Praktis untuk Mengenal Allah, terj. Johny The. Yogyakarya: Andi Offset, 2009.

Paterson, Janis E., Jeff Field, dan Jan Pryor. "Adolescents' Perceptions of Their Attachment Relationships with Their Mothers, Fathers, and Friends." Journal of Youth and Adolescence 23, no. 5 (1994): 579-600. Diakses 14 September 2017. http://dx.doi.org/10.1007/BF01537737.

Pearce, Lisa D., dan Melinda Lundquist Denton. A Faith of Their Own. New York: Oxford University Press, 2011.

Raja, Shyamala Nada, Rob Mcgee, dan Warren R. Stanton. "Perceived Attachments of Parents and Peers and Psychological Well-Being and Adolescence." Journal of Youth and Adolescence 21, no. 4 (1992): 471-485.

Regnerus, Mark D. "Shaping Schooling Success: Religious Socialization and Educational Outcomes in Metropolitan Public Schools." Journal for the Scientific Study of Religion 39, no. 3 (2000): 363-370. Diakses 29 November 2017. http://dx.doi. org/10.1111/0021-8294.00030.

-. "Religion and Positive Adolescent Outcomes: A Review of Research and Theory." Review of Religious Research 44, no. 4 (2003): 394-413. Diakses 23 Oktober 2017. http://dx.doi.org/10.2307/3512217. 
Regnerus, Mark D., dan Glen H. Elder. "Staying on Track in School: Religious Influences in High- and Low-Risk Settings." Journal for the Scientific Study of Religion 42, no. 4 (2003): 633-649. Diakses 29 November 2017. http://dx.doi. org/10.1046/j.1468-5906.2003.00208.x.

Rew, Lynn, dan Y. Joel Wong. "A Systematic Review of Associations among Religiosity/Spirituality and Adolescent Health Attitudes and Behaviors." Journal of Adolescent Health 38, no. 4 (2006): 433-442. Diakses 23 Oktober 2017. http://dx.doi. org/10.1016/j.jadohealth.2005.02.004.

Rostosky, Sharon Scales, Brian L. Wilcox, Margaret Laurie Comer Wright, dan Brandy A. Randall. "The Impact of Religiosity on Adolescent Sexual Behavior: A Review of the Evidence." Journal of Adolescent Research 19, no. 6 (2004): 677697. Diakses 23 Oktober 2017. http://doi. org/10.1177/0743558403260019.

Ryan, Richard M., dan Cynthia L. Powelson. "Autonomy and Relatedness as Fundamental to Motivation and Education." Journal of Experimental Education 60, no. 1 (1991): 49-66.

Salkind, Neil J. Statistics for People Who (Think They) Hate Statistics. London: Sage, 2005.

Samuolis, Jessica, Kiera Layburn, dan Kathleen M. Schiaffino. "Identity Development and Attachment to Parents in College Students." Journal of Youth and Adolescence 30, no. 3 (2001): 373-384. Diakses 15 Agustus 2017. http://dx.doi. org/10.1023/A:1010448313516.

Santrock, John W. Perkembangan Masa Hidup Jilid 1. Diterjemahkan oleh Benedictine Widyasinta. Ed. ke-13. Jakarta: Erlangga, 2011.

Schwartz, Kelly Dean. "Transformations in Parent and Friend Faith Support Predicting Adolescents' Religious Faith." The International Journal for the Psychology of Religion 16, no. 4 (2006): 311-326.
Diakses 28 September 2017. http://dx.doi. org/10.1207/s15327582ijpr1604_5.

Sevilla, Consuelo G., Jesus A. Ochave, Twila G. Punsalan, Bella P. Regala, dan Gabriel G. Uriarte. Pengantar Metode Penelitian. Jakarta: UI Press, 1993.

Shin, Heuikwang. "Asian-American College Students' Parental Attachment and Their Relationship with God," Christian Education Journal 6, no. 2 (2009): 353-375. Diakses 6 September 2017. https://doi. org/10.1177/073989130900600212.

Siregar, Syofian. Statistika Deskriptif untuk Penelitian: Dilengkapi Perhitungan Manual dan Aplikasi SPSS Versi 17. Jakarta: RajaGrafindo Persada, 2014.

Smith, Christian, dan Melinda Lundquist Denton. Soul Searching: The Religious and Spiritual Lives of American Teenagers. New York: Oxford University Press, 2005. Adobe PDF ebook.

Soeherman, Sylvia. Kuliah Statistik. Malang: SAAT, 2015.

Stark, Rodney dan Charles Y. Glock. American Piety: The Nature of Religious Commitment. Berkeley: University of California Press, 1968. Adobe PDF ebook.

Strathmann, Hermann. Theological Dictionary of the New Testament IV. Diedit oleh Gerhard Kittel dan Gerhard Friedrich. Diterjemahkan oleh Geoffrey G. Bromiley. Grand Rapids: Eerdmans, 1967. Libronix 3.

Suryabrata, Sumadi, dan Restu Kartiko Widi. Asas Metodologi Penelitian: Sebuah Pengenalan dan Penuntun Langkah demi Langkah Pelaksanaan Penelitian. Yogyakarta: Graha Ilmu, 2010.

Susman, Elizabeth J., dan Alan Rogol. "Puberty and Psychological Development." Dalam Handbook of Adolescent Psychology, diedit oleh Richard M. Lerner dan Laurence Steinberg, 15-44. 2 ed. New 
Jersey: John Wiley \& Sons, 2004. Adobe PDF ebook.

Tanudjaja, Rahmiati. Kuliah Teologi Sistematika. Malang: SAAT, 2014.

Taris, Toon W., dan Gün R. Semin. "Passing on the Faith: How Mother-Child Communication Influences Transmission of Moral Values." Journal of Moral Education 26, no. 2 (1997): 211-221. Diakses 18 Desember 2017. http://dx.doi. org/10.1080/0305724970260208.

Utley, Bob. How It All Began: Genesis 1-11. Marshall: Bible Lessons International, 2001.

van IJzendoorn, Marinus H., dan Abraham Sagi-Schwartz. "Cross-Cultural Patterns of Attachment." Dalam Handbook of Attachment: Theory, Research, and Clinical Applications, diedit oleh Jude Cassidy dan Phillip R. Shaver, 880-905. Ed. ke-2. New York: Guilford, 2008. Adobe PDF ebook.

Weems, Carl F., Steven L. Berman, Wendy K. Silverman, dan Eileen T. Rodriguez. "The Relation between Anxiety Sensitivity and Attachment Style in Adolescence and Early Adulthood." Journal of Psychopathology and Behavioral Assessment 24, no. 3 (2002): 159-168. Diakses 14 September 2017. http://dx.doi. org/10.1023/A:1016058600416.

Weigert, Andrew J., dan Darwin L. Thomas. "Parental Support, Control and Adolescent Religiousity: An Extension of Previous Research." Journal for the Scientific Study of Religion 11, no. 4 (1972): 389393. Diakses 28 September 2017. ATLA Serials.
Weinfield, Nancy S., Alan L. Sroufe, Byron Egeland, dan Elizabeth Carlson. "Individual Differences in Infant-Caregiver Attachment: Conceptual and Empirical Aspects of Security." Dalam Handbook of Attachment: Theory, Research, and Clinical Applications, diedit oleh Jude Cassidy dan Phillip R. Shaver, 78-101. Ed. ke-2. New York: Guilford, 2008. Adobe PDF ebook.

Widi, Restu Kartiko. Asas Metodologi Penelitian: Sebuah Pengenalan dan Penuntun Langkah demi Langkah Pelaksanaan Penelitian. Yogyakarta: Graha Ilmu, 2010.

Wenham, Gordon J. Genesis 1-15. Word Biblical Commentary 1. Dallas: Word, 2002. Libronix 3.

Williams, Susan K., dan F. Donald Kelly. "Relationships Among Involvement, Attachment, and Behavioral Problems in Adolescence: Examining Father's Influence." Journal of Early Adolescence 25, no. 2 (2005): 168-196. Diakses 16 April 2018. http://dx.doi. org/10.1177/0272431604274178.

Wong, Y. Joel, Lynn Rew, dan Kristina D. Slaikeu. "A Systematic Review of Recent Research on Adolescent Religiosity/Spirituality and Mental Health." Issues in Mental Health Nursing 27, no. 2 (2006): 161-183. Diakses 23 Oktober 2017. http:// dx.doi.org/10.1080/01612840500436941.

Youniss, James, Jeffrey A. McLellan, dan Miranda Yates. "Religion, Community Service, and Identity in American Youth." Journal of Adolescence 22 (1999): 243-253. Diakses 28 November 2017. http://dx.doi. org/10.1006/jado.1999.0214. 